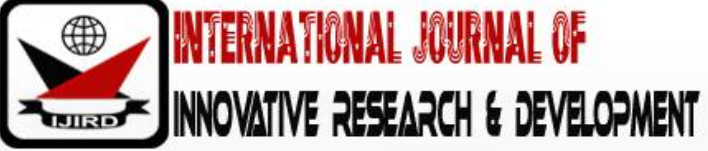

ISSN 2278 - 0211 (Online)

\section{Influence of Mergers and Acquisitions on New Technology Adoption by Mobile Network Operators in Ghana}

\author{
Kwaku Mensah Dorgbetor \\ Accountant, Department of Finance and Administration, Rimal Ghana Ltd, Ghana
}

\begin{abstract}
The 1990s onwards recorded a wave of cross-border mobile network operator mergers across the world, including Vodafone Group's acquisition of majority stake in the state-owned Ghana Telecom (GT) in August 2008 and Bharti Airtel taking over Zain Ghana operations as part of its acquisition of Zain Africa in July 2010. The objective of this study was to assess the influence of mergers and acquisitions on deployment of new mobile technologies using two Ghanaian mobile telecommunication companies as case studies. The study adopted a qualitative research methodology involving the analysis of secondary data, mainly relevant news reports and company reports. The study identified five major themes which largely influenced their investment and technology deployment decisions. First, the need for market growth, revenue increase, and brand extension were found to be the primary motives for the acquisitions. Second, it was found that one of the Companies had to deal with political and legal uncertainties that characterised the acquisition of a strategic national incumbent, thus delaying new technology deployment. Third, the analysis revealed that one of the companies again had to embark on far reaching organizational change and restructuring processes in order to reduce cost as well as to position itself favourable for the competitive telecom market. Fourth, the study found that both companies following the completion of the acquisition and ensuing matters being addressed made significant investments to upgrade their network infrastructure and technology. Finally, the analysis showed the perception of the technology, company policy and other factors also influenced the pace of technology deployment. The overall conclusion of the findings is that the acquisitions provided incentives for the case study telecom companies to expand their network infrastructure and deploy new technologies.
\end{abstract}

Kevwords: Mercers and acquisitions; mobile network operators

\section{Introduction}

\subsection{Background}

The telecommunications industry is one of the fastest growing sectors of the global economy within the last three decades (Gantumur \& Stephan, 2007; GSMA 2014a). The mobile sub-sector in particular recorded dramatic growth and sophistication over the last ten years. GSMA (2014a) has reported that at the end of 2003, there were a little more than one billion unique mobile service subscribers globally, and by the end of 2013 this figure had increased to 3.4 billion, a growth trend driven largely by increasing worldwide demand for data services and rising mobile penetration in emerging markets like Africa(Vodafone Group Plc, 2014). In terms of both unique subscribers and connections, Sub-Saharan Africa (SSA) has been the fastest growing region in the last five years. As of June 2014, the region recorded 329 million unique subscribers, representing a penetration rate of 38 percent, and more than 608 million connections. In 2013, the mobile industry in SSA contributed 5.4 percent to overall gross domestic product (GDP), and this is expected to increase to 6.2 percent by 2020(GSMA, 2014 b). Mobile technologies have opened new unimaginable channels of communication between and among individuals, businesses and governments across the world. No other technology in history has been more accessible to so many people in so many countries in such a short period of time than mobile telephony(World Bank, 2008)

This largely explained why mobile telephony has become a cornerstone of the global economy, both as an industry in its own right and as a facilitator of opportunities in other sectors. The mobile industry contributed about 3.6 percent to the global gross domestic product (GDP) in 2013, equivalent to more than US\$ 2.4 trillion. This figure could increase to 5.1 percent of global GDP by 2020. In addition, there are 10.5 million jobs supported directly by the mobile telecommunications industry(GSMA, 2014b). More importantly, the mobile industry has also played a crucial role in the global economy as an innovation platform for new information and communication technology uptake(GSMA, 2014 b).

A number of factors accounted for this breath-taking growth in global telecommunications in terms of technology and structure. First, reforms in regulatory policy frameworks in both the developed and developing world introduced deregulation and liberalisation leading to rapid growth and diversification(Ase \& Apan, 2005; Schonberger \& Strasser, 
1999). Ghana deregulated its telecommunications sector in 1994, when the Government adopted a five-year comprehensive sector policy reform dubbed the "Accelerated Development Programme 1994-2000" (MTC 1999). As a result, telecommunications service delivery in Ghana and elsewhere in the world evolved from state monopoly and control to market competition. Second, the wave of rapid technological innovations and developments in the sector created new market opportunities for industry players and allowed for new entrants into the once highly regulated industry. The advent of new technologies and products also prompted the increasing demand for different telecommunications services by customers(Ase \& Apan, 2001).

Gantumur and Stephan (2007) have noted that it was in response to the evolving market forces, principally deregulation and liberalisation, rapid technological change and digital convergence that led to the enormous wave of Mergers \& Acquisitions (M\&A) that have been witnessed in the telecommunications industry in the 1990s. Le Blanc and Shelanski (2002) have reported that between 1996 and 2001 alone, more than 20 M\&A deals worth more than US\$20 billion were reached in the telecommunications sector, 14 of which took place the United States of America.

In line with the global trend, deregulation and liberalisation of Ghana's telecommunications sector in the mid1990s ushered in competition and a radical transformation that created new opportunities and new challenges for cellular telephony infrastructure and service providers(Ase \& Apan, 2001 ). The rapid technological change, growing technological complexity and the expanding portfolio of new products added new dimension to an already complex and fast evolving industry. These developments perhaps contributed to the wave of M\&A of mobile telecommunication companies, some of which had presence in Ghana. For instance, in 2006 South Africa-based Pan-African Mobile Telecommunications Network (MTN) took advantage of growth prospects in the emerging Ghanaian market to acquire Beirut-based Investcom, the parent company of Scancom, which operated the Spacefon-Areeba brand in Ghana and re-branded it as MTN. The motive of MTN for acquiring Investcom was to build the largest mobile provider across Africa(MTN Group Limited,2006.). In August 2008, Vodafone, the world's largest mobile telecommunications group announced acquisition of a 70 percent stake in Ghana Telecom for a total of US\$900 million ( $£ 452$ million), with the Government of Ghana retaining a 30 percent interest. Announcing the deal, Arun Sarin, Chief Executive of Vodafone, said Ghana was one of the most attractive markets in Africa with mobile subscribers growing at more than 55 percent per annum and mobile penetration growing at a much faster rate. And so the extensive global operating experience of Vodafone coupled with its portfolio of diverse products and services will position the company well to deliver a superior mobile experience to Ghanaian customers, the Vodafone Group Chief Executive said(Vodafone Group, 2008). The third significant acquisition that affected the fortunes of a mobile telecom service provider in Ghana was when Bharti Airtel of India acquired the African operations of Kuwait-based Zain Telecom for US\$10.7 million in March 2010. Zain was then operating in 17 African countries, including Ghana, and Airtel acquired Zain operations in all the countries, except in Sudan and Morocco (The New Times of India, 2010). On the reason for the acquisition, Sunil Mittal, Chief Executive of Bharti Airtel indicated that the transaction was "the largest ever crossborder deal in an emerging market and will result in combined revenues of about US\$13 billion". The motives cited for these strategic acquisitions support the evidence that telecom companies may prefer M\&A, because M\&A provide an immediate controlling presence in the new, fast expanding market, rather than having to gradually build a new business from scratch (Capron \& Mitchell, 1997; Gantumur \& Stephan, 2007). In fact, other players in the telecom industry have argued that M\&A would enable them to deploy cutting edge technologies at a lower cost. For instance, more recently the U.S Department of Justice initiated measures to stop AT\&T's acquisition of T-Mobile USA from Deutsche Telekom based on the concern that the merger would create duopoly market associated by higher prices and less innovation. In a rebuttal, the merging companies argued that the merger would rather enhance their abilities to adopt an advanced wireless technology. AT\&T had argued that acquiring T-Mobile's radio spectrum would make it more economical to deploy fourth generation $(4 \mathrm{G})$ wireless communications services to a wider American population - including rural communities and small towns(Jamison \& Hauge, 2013; AT\&T, 2011)).

While several studies have pointed out that the telecommunications industry has undergone major restructuring in terms of technological innovation and structure in the 1990s through intense M\&A activity (Jamison \& Hauge, 2013). There is no death of empirical studies investigating how the recent telecom companies M\&A has influenced the deployment and adoption of new technological innovations in emerging markets.

\subsection{Problem Statement}

Emerging markets in the developing world of Asia and SSA have been described as the engines of growth in the new global market place for mobile telephony services(Vodafone Group Plc, 2011;Aker \& Mbiti, 2010). Large segments of the population on these continents who hitherto had limited or no access to modern telecommunications catapulted generations of technology through the advent of mobile telephony and the convergence of information and communication technologies(Han, Ahn \& Skudlark, 2004).

Africa recorded one of the fastest growth in mobile cellular telephone usage in the 2000s, reaching nearly 246 million subscriptions by the end of 2008, and mobile penetration grew from under five percent in 2003 to more than 33 percent in 2008(ITU, 2009.). Interestingly, the rapid uptake of mobile telephone usage in Africa is partly as a result of the very poor having embraced mobile telephony to improve their socio-economic wellbeing, and at the same time offering great opportunities for service providers to increase their subscriber base by developing new innovative solutions targeting the poor. A win-win situation which Prahalad (2010) described as "the fortune at the bottom of the pyramid".

In Ghana, mobile phones have significantly reduced the costs of communication allowing individuals and businesses to send and to access information quickly and at a lower cost on diverse range of economic, political and social issues. Mobile operators have introduced voice services and increased internet access widely; and benefitted poor rural communities through the provision of mobile money services and thus propelling economic growth(Aker \& Mbiti, 2010; 
GSMA, 2014a). Prior to the deregulation of the Ghanaian telecommunications sub-sector in the 1990s, the main provider of telephone services (fixed line) was the state-owned Post and Telecommunication Corporation (P\&T), which was later transformed into Ghana Telecommunications Company Limited. As a result, access to telephone services was not only restricted, the state monopoly also charged exorbitant rates beyond the reach of most people but provided poor quality services(Boohene, 2011; Allotey \& Akorli, 2001).

Mobitel, a network service provided by Milicom Ghana Limited became the first mobile (cellular) phone service to be introduced in Ghana in 1991. It operated an analogue network system that was very popular among the rich and elite in society. The service was in high demand and had recorded 22000 subscribers by 1998, controlling about 70 per cent of the mobile telephony market. CellTell, owned by Kludjeson International, came into the market by launching the American Mobile Phone System (AMPS) technology in 1993, which covered only parts of Accra and Tema. Then, Scancom Limited revolutionised the Ghanaian mobile telephony landscape dramatically when it launched the first GSM service in November 1996 under the brand name of Spacefon. And in 2000, Ghana Telecom followed suit by launching its nation-wide ONE touch GSM cellular service(Ase \& Apan, 2001; Sankaran et al., 2011).

Currently, there are six major mobile telecommunications companies operating in Ghana under stiff competition. They are GT/ Vodafone Mobile (Ghana), Scancom (MTN), Airtel Mobile, Millicom (Tigo), Expresso and Glo Mobile. As noted earlier, the current status of three of the bigger players in the Ghanaian mobile phone sector - Scancom (MTN), GT/Vodafone and Airtel resulted from cross-border mergers and acquisitions. In 2009, the Ghanaian mobile telephony sub-sector accounted for five percent of mobile phone subscriptions in SSA (ITU, 2009)(). Statistics from the National Communications Authority (NCA) reported that Ghana's Mobile Voice subscriber base increased marginally by 0.47 percent in December from November, 2014, to bring total subscriptions for the period to 30,360,771. Hence, the current penetration rate stands at $113.37 \%$. MTN had a 45.63 percent share of the mobile voice market, followed by Vodafone with 23.3 per cent, Tigo (13.62\%), and Airtel Mobile controlling 12.30 percent(NCA, 2014).

The rapid growth in mobile phone subscriptions is an indication of the telecom companies' commitment to continue growing their subscriber base by introducing new innovative technologies into the Ghanaian market, and at the same time taking full advantage of economies of scale. The contribution of mobile telephony to the Ghanaian economy cannot be overemphasized. Mobile telephony has made a significant positive impact both directly and indirectly in terms of its contribution to GDP growth, job creation, increase in productivity, and increase in tax revenue. GSMA/ Deliotte (2012) have reported that as new technologies are developed, mobile services could extend the frontiers of socioeconomic development further through the provision of cutting edge 3G and 4G data services accessed via smartphones, tablets and other devices that deliver mobile data and voice packages. The report found that for any given level of total mobile penetration, a 10 percent shift from $2 \mathrm{G}$ to $3 \mathrm{G}$ penetration would likely increase GDP per capita growth by 0.15 percent(GSMA, 2014; Deliotte, 2012:2). This suggests that as the Ghanaian mobile market is almost at the saturation point, mobile operators would have to invest massively in new technologies. Studies on the influence of mergers and acquisition on the adoption of new technologies in the telecommunications sector are generally limited(Jamison \& Hauge, 2013; Gantumur \& Stephen, 2007), more so in an emerging market like Ghana. This study sought to contribute to filling this gap in empirical knowledge by investigating how mergers and acquisitions influence mobile telecommunications companies' motivation for adopting new technologies that increase or sustain their subscriber base and competitiveness. The question is can M\&A serve as a platform for telecommunication firms in emerging markets to rapidly adopt new technologies?

\subsection{Research Questions}

The study will seek to answer the following specific research questions:

- What are the current technologies used by the mobile telecommunication companies?

- In what respect are the technologies and products used by the companies fundamentally different and why?

- Did the mergers and acquisitions provide incentives for the mobile telecommunication companies to rapidly deploy new technologies and services?

- Did the adoption of new technologies affect the competitiveness of mobile telecommunication firms?

\subsection{Objectives of the Study}

The main objective of this study was to investigate the influence of mergers and acquisitions on mobile telecommunication companies' motivation to rapidly adopt new technologies for overall business performance in Ghana.

\subsubsection{Specific Objectives}

The specific objectives of this study were:

- To establish the goals and objectives for acquiring the Ghanaian telecommunication companies.

- To identify and document the current technologies used by mobile telecommunication companies.

- To establish the technology and product differentiation strategies adopted by mobile telecommunication companies in order to be competitive.

- To assess whether mergers and acquisitions have led mobile telecommunication companies to more rapidly adopt new technologies and services.

- To assess whether adoption of the new technologies has affected the competitiveness of mobile telecommunication companies. 


\subsection{Significance of the Study}

The focus of this study is to investigate the extent to which (M\&A) provide incentives for telecommunication firms to deploy cutting edge technologies that increase service quality to customers and at same time allow them to stay competitive. In this regard, if the real motive for M\&A is to upgrade technologies that would provide superior services, then it is win-win situation for both customers and the firms involved. However, it is sometimes the case that firms may decide to use M\&A as a cover up for other ulterior motives such as wanting to dominate the market or monopolize the development of new technologies to the detriment of consumers and competitors. This has often resulted in conflicts between regulators and deal makers when regulators express concerns(Jamison \& Hauge, 2013; Rosenthal, 2012.). It is in this context that M\&A deal makers in the telecoms and related industries can learn a lot from the findings of this study if the aim of M\&A deal proposals is to facilitate the adoption of new technologies. In fact, they could use findings from the study to make a case for M\&A that regulators may not want to support. On the other hand, the study findings would provide telecom sector regulators, such as the NCA, in emerging markets like Ghana to either support or discourage some proposed M\&A deals in the sector that would affect telecommunications operators in their countries. As very little research has been conducted on the topic, especially from a developing country perspective, the study findings would be invaluable in contributing empirical knowledge on the field. In fact, the findings of this study could be useful for the management of the case study telecom firms who were either involved during the M\&A negotiations or have been part of the implementation process.

\subsection{Limitations of the Study}

The findings presented in this study was based on secondary data comprising 17 news articles/ news releases, 7 case study company annual reports, 3 other related publication. The secondary material was drawn from the period Vodafone acquired GT, i.e. years 2008-2015. Like all other research endeavours, this study also has its own limitations for various reasons. To start with, the observed phenomena were approached from the subjective viewpoint or interpretation of the researchers, even assuming the existence of factual reality; it is difficult to objectively achieve as the observations are distorted by the observers' own values, feelings and motivation. In order to enhance validity and reliability, the study relied on triangulation over multiple data sources secondary data. In fact, it was for this reason that the study initially incorporated the collection of primary data to further support the secondary data. Unfortunately, the target respondents declined to complete the questionnaires. As a result, the number of data sources was further limited and due to the dearth of available academic research in this particular field of study, the paper has relied mostly on non-academic secondary data (news reports and grey publications) whose reliability, in some cases, cannot be certain.

Furthermore, while there was much information on Vodafone/ GT that on Airtel was very scanty. The analysis was based on two cases (companies) to provide an opportunity for comparison in a single market, but the unavailability of enough data on Airtel limited the level of comparison. In addition, as a qualitative case study focusing on only two companies does not allow for generalization of the findings to other markets or companies and the study was meant to be considered only as descriptive rather than normative. Despite these limitations, the study makes an invaluable contribution to the understanding of mergers and acquisitions regarding the deployment of technological innovations in the Ghanaian telecommunications industry.

\subsection{Overview of the Paper}

The paper is made of six sections. Section one is an introduction of the background of the study, the problem statement, research questions, and objectives of the study. It also includes the scope of the study, the significance, and the limitations of the study. Section two gives an overview of the mobile communications industry and mobile telecommunications landscape in Ghana. First, a general overview of the industry is presented. Then the mobile technology standard is explained to give context to the study. Section three is next with a brief overview of M\&As. M \& As concept definitions, followed by a classification of $M \& A s$; then an overview of $M \&$ As in the telecommunications industry from a global perspective. Section four states the methodology which has been adopted for this study. The case study method was adopted because it is related to the purpose of the study. Section five presents an analysis of the data collected, while Section six presents conclusions drawn from the analysis.

\section{Industry Background and Mobile Telecoms Landscape in Ghana}

\subsection{Introduction}

This chapter gives an overview of the mobile communications industry and mobile telecommunications landscape in Ghana. First, a general overview of the industry is presented. Then the mobile technology standard is explained to give context to the study. This is followed by a description of operations of the major stakeholders of interest to the study mobile network operators (MNOs), and finally a brief overview of the mobile communications value system is presented.

\subsection{Overview of Mobile Cellular Industry}

Mobile cellular telephony became commercially available in the early 1980s in most parts of the developed world (ITU, 2010a) (), but was not introduced into the Ghanaian market until 1991. However, the service became commercially and widely available in Ghana in the latter part of the 1990s. Currently, the mobile-cellular industry is one of the largest communication sectors in the world with almost seven billion users worldwide, the fastest growth taking place in the socalled emerging markets in Africa and Asia(Vodafone Group, 2012; ITU, 2014a ). The industry generates around US\$960 billion of annual service revenue, 80 percent of which comes from standard voice calls and text messaging. Within the last 
ten years the share of telephone calls via mobile has increased from 20 percent to 74 percent, reflecting the benefits of mobility. Similarly, in 2011, 4.3 trillion text messages were sent(Vodafone Group, 2012).

Mobile cellular telephony allows the phones of subscribers to communicate via signals carried in the electromagnetic radio spectrum. Unlike other forms of radio communications, cellular technologies allow customers to move about without hindrance while continuing a communications session(Padgett, Gunther, \&Hattori, 1995). This is accomplished by the division of geographic areas into cells, each of which is served by a radio antenna, and using the cellular technology to transfer a customer from one cell to another as the customer moves. This is often achieved without disrupting the customer's connectivity as long as each cell involved in the session has sufficient capacity to serve all of the customers trying to engage in sessions simultaneously in that cell(Jamison \& Hauge, 2013).

The strong growth of the mobile-cellular industry is driven by rapid innovations in technologies, availability and uptake of more affordable devices (smartphones), applications and networks. Voice applications used to be the dominant revenue source of mobile telecommunications service providers in emerging countries; but new technologies and huge demand for low cost phones that enable voice and data services to be deployed is providing solid growth in mobile phone penetration ("ITU, 2014a)). By the end of 2013, mobile broadband penetration peaked at 84 percent in the developed world market, compared with 21 percent in developing country markets.

\subsection{Mobile Technology Standard}

The mobile telecommunications technology standard is changing at a breath taking speed, with services increasingly shifting from voice to data and from circuit-switched to packet-switched systems (Raut, 2009). This necessitated the continuing evolution of various generations of mobile standards. The first generation (1G) mobile cellular networks employed analogue technology. Rapid developments in digital technology in the early 1980s ushered in second generation (2G) systems, and by the end of the 1980s $2 \mathrm{G}$ networks had been well developed and deployed worldwide to provide better quality services, greater capacity and additional functionality than analogue systems (Liu, 2010). The world had almost completed the transition to digital cellular networks at the end of 2002, with analogue users representing a mere three per cent of total mobile subscribers (ITU, 2010a). The switch from analogue to digital brought about significant improvement, both in call quality and reliability. Cellular phone gained its widespread popularity at this stage (ITU, 2010a). There are four $2 \mathrm{G}$ digital cellular radio technology standards worldwide, but the Global System for Mobile Communications (GSM) is the dominant standard, with an estimate of 80 percent market share. The widespread popularity of GSM can be attributed to the fact that it is an open non-proprietary standard (Liu, 2010). GSM network operators in Ghana include Vodafone, MTN, TiGo and Airtel. As at December 2002, there were 788 million GSM subscribers on 467 networks in 169 countries. Code Division Multiple Access (CDMA), which is a standard developed by Qualcomm, comes next after GSM in terms of popularity. CDMA enables mobile users to share the same frequency band. Contrast to GSM, CDMA is not free. A royalty fee has to be paid to the developers (Qualcomm) for use of the technology (Liu, 2010). Expresso is the only network operator in Ghana that deploys CDMA. At December 2002, there were 147 million CDMA subscribers with 61 per cent in the Americas, 37 per cent in the Asia-Pacific region and less than two per cent in Europe, the Middle East and Africa (ITU, 2010a; Sauter, 2009 ).

Despite several intermediate steps (upgrades) that came in the form of $2.5 \mathrm{G}$ and $2.75 \mathrm{G}$ technologies, the first widely used cellular broadband was made possible with the introduction of the third generation (3G) technologies (Jamison and Hauge, 2011). It is much easier to distinguish $1 \mathrm{G}$ wireless standard from $2 \mathrm{G}$ technologies because the former was based on analogue signals while the latter introduced digital signals. However, it is a bit difficult to seamlessly differentiate between $2 \mathrm{G}$ and $3 \mathrm{G}$ technologies. A primary difference between the two is that $3 \mathrm{G}$ technologies allowed for greater data transmission and for certain types of video transmission (Jamison and Hauge, 2011). While 2G digital wireless technologies increased voice capacity to deliver quality mobile service to consumers, 3G optimized wireless broadband connectivity for enhanced data transmission. In other words, 3G provides superior data services than 2G, but lacks sufficient functionality and bandwidth for many advanced services(FCC, 2011; Frattasi et al., 2006; Hui andYeung, 2003). The $3 G$ of GSM includes WCDMA (Wideband Code-Division Multiple Access) and UMTS (Universal Mobile Telecommunications System). The 3G of CDMA includes 1xRTT, EV-DO, EV-DO Rev A (Liu, 2010).

The fourth generation (4G) of wireless cellular technologies are being developed and deployed motivated by the increasing demand for mobile broadband services with higher data rates and Quality of Service (QoS) and also to address the deficiencies of 3G systems (Akyildiz et al., 2010:217). Currently, there are competing 4G mobile technologies such as HSPA+, WiMAX and LTE (Akyildiz et al., 2010; Rysavy Research, 2012; Rohde and Schwarz, 2012; FCC, 2011; Akyildiz et al., 2010; Sauter, 2009). HSPA+ is a higher bandwidth form of HSPA (High Speed Packet Access), which is used in some 3G networks. An advantage of HSPA+is that it can evolve from some 3G networks. Some industry players consider LTE (Long Term Evolution) and WiMAX (Worldwide Interoperability for Microwave Access) as being more advanced and offering higher data transfer speeds than HSPA+, but they cannot evolve from existing $3 \mathrm{G}$ networks and so require additional radio spectrum(FCC, 2011; Raut, 2009).

The future deployment of $4 \mathrm{G}$ technologies by cellular network operators will largely depend on the availability of bandwidth in the radio spectrum. To deliver the advanced services promised, LTE deployment will require additional unencumbered radio spectrum. Radio spectrum is unencumbered in this context if it is not currently being used for other services like for military purposes or other technologies (Jamison and Hauge, 2011). This could present a major challenge for service providers because governments may be slow in providing additional radio spectrum for $4 \mathrm{G}$ services. However, there is general consensus that additional radio spectrum for cellular service would facilitate rapid deployment of $4 \mathrm{G}$ technologies that could propel rapid economic development in emerging countries (GSMA/ Deliotte, 2012; Jamison and Hauge, 2011; Rysavy Research, 2012). 


\begin{tabular}{|c|c|c|c|}
\hline & 1st Generation & $2^{\text {nd }}$ Generation & $3^{\text {rd }}$ Generation \\
\hline Application & $\begin{array}{c}\text { National/ local systems, } \\
\text { Portable phones, Car } \\
\text { phones. }\end{array}$ & $\begin{array}{l}\text { Regional systems, Pocket } \\
\text { phones, Digital voice } \\
\text { services, Digital text: SMS } \\
\text { (short message service), } \\
\text { First-generation WAP }\end{array}$ & $\begin{array}{c}\text { Global system, Integrated } \\
\text { high-quality audio and } \\
\text { data, Music and video, } \\
\text { Narrowband and } \\
\text { broadband, Multimedia } \\
\text { services. }\end{array}$ \\
\hline $\begin{array}{l}\text { Type of } \\
\text { System }\end{array}$ & $\begin{array}{c}\text { Analogue cellular } \\
\text { technology. } \\
\text { Macro-cellular systems }\end{array}$ & $\begin{array}{c}\text { Digital cellular } \\
\text { technology. Micro- } \\
\text { cellular and pico-cellular. } \\
\text { Enhanced cordless } \\
\text { technology. }\end{array}$ & $\begin{array}{l}\text { Digital broadband. } \\
\text { Information } \\
\text { compression. Higher } \\
\text { frequency spectrum. } \\
\text { IP packet switching. }\end{array}$ \\
\hline Standard & $\begin{array}{l}\text { AMPS, ETACS, NMT 450, } \\
\text { NMT 900, TACS, } \\
\text { Radiocom 2000, C-450, } \\
\text { RTMS, Comvik. }\end{array}$ & $\begin{array}{l}\text { GSM, CDMA, TDMA, PDC, } \\
\text { GPRS. }\end{array}$ & $\begin{array}{c}\text { WCDMA/ HSPA, CDMA } \\
\text { 2000/ EV-DO, TDMA 126, } \\
\text { UTMS, TD-SCDMA }\end{array}$ \\
\hline
\end{tabular}

Table 1: Summary of Mobile Technology Standards

\subsection{Mobile Network Operators}

Mobile subscribers need cellular networks to provide them with services. Thus, mobile network operators (MNO) are companies that acquire radio frequency spectrum from the government to provide services to users and other content providers. In fact, MNOs have played and continue to play a central role in the mobile communication landscape since the beginning of 1G technologies deployment up to date. It is therefore logical to reason that since MNOs need to acquire spectrum from governments, their activities should be restricted to regional or national level companies. On the contrary, powerful multi-national companies such as Vodafone and Bridge Alliance, which have subsidiaries across the globe, dominate the market (Liu, 2010).

The leading MNO conglomerates in terms of subscribers at end of 2014 include $^{1}$

- China Mobile (operate in China, Hong Kong, Pakistan, Thailand)

- Bridge Alliance and Sing Tel (operate in Australia, Asia, Africa)

- Vodafone (operate in Europe, Brazil, Africa, Asia, New Zealand)

- $\quad$ Airtel (Asia, Africa)

- China Unicom (operate in China, including Macau)

- America Movil (operate in USA, South America)

- Telefonica (operate in Europe, South America, Africa).

Cross-border mergers and acquisitions have become common in the MNO market because it provides the opportunity to quickly expand a wide range of services, reduce operational costs through restructuring and to deploy new technologies across borders. For instance, there have been recent mergers in Europe, particularly in the UK, Germany, Ireland and Austria that sought to reduce the number of operators in those markets to at least two or three (GSMA, 2014c). In September 2009, Orange and T-Mobile announced a deal to merge their UK operations to create the UK largest MNO, with 28.4 million customers, and representing 37 percent market share (Wray, 2009). Similarly, in June 2010, Bharti Airtel of India sealed a major acquisition of Kuwait-based Zain Group's mobile operations in 16 Africa countries in order to take advantage of the continent's emerging market (Healy, Palepu, \& Rubak, 1990). Liu (2010) has noted that new entrants and new MNOs from M\&A continuously find themselves in a market with severe competition where competitive advantages, market share, and customer base are difficult to cultivate and maintain. To ward off competition, MNOs in both developed and developing countries have used various strategies, including lobbying regulators not to set rules for more open competition (Liu, 2010).

The mobile telephony industry consists of several strongly interdependent actors and competitors. Although the presence and significance of each player may vary from market to market, yet there is fairly consistent set of actors everywhere known as the mobile phone value system (Solvell and Porter, 2011). As shown in Figure 1, the mobile communications value system consists of five principal actors: the mobile network operators, the content providers, the application providers, the infrastructure manufacturers, and the device providers, and ultimately the end consumer (user). Of course, there are intermediary players along the value system. Prior to the worldwide liberalisation and deregulation of the telecom industry in the 1990s, network operators hitherto strictly controlled and managed many functions, including absolute control over physical network infrastructure, services, content, marketing and billing ( Cricelli et al., 2011). Hence, with the introduction of new technical platforms and ICT convergence, the value system has become more diversified and complex (Cricelli et al., 2011). 


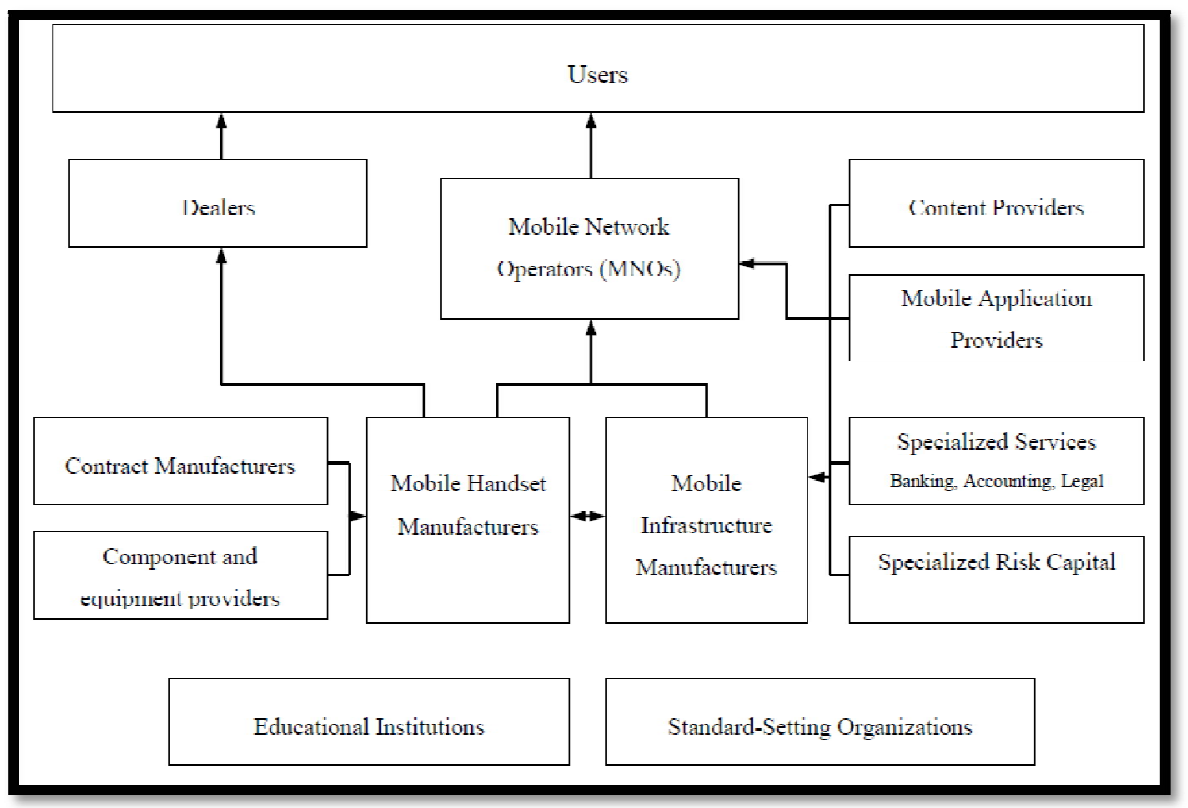

Figure 1: Mobile Phone Value Systems

Source: Adapted from Solvell and Porter (2011)

\subsubsection{Ghanaian Mobile Network Operators (Mnos) and Market Share}

This section briefly describes the six mobile network operators in the Ghanaian market namely MTN, GT/Vodafone Mobile, Millicom (TiGo), Airtel, Glo and Expresso.

\subsubsection{Mobile Telecommunication Company (MTN)}

MTN Group of South Africa acquired Investcom, the parent company of Scancom Ghana limited in July 2006. The acquisition enabled the company to improve its network coverage and quality resulting in an increase in subscriber base from 2.6 million in 2006 to 4.0 million at the end of December 2007 (MTN Group, 2008). The Company also introduced new products and innovative services, including GPRS roaming, Me2U, and international call-back services into the Ghanaian market. It made further progress in expanding the network infrastructure (MTN Group, 2006, 2008)). Scancom, which launched the first digital GSM network in Ghana, was acquired by Dubai-based Investcom LLC in 2005 and renamed the network from Spacefon to Areeba. The MTN acquisition of Investcom in 2006 rebranded the network again to MTN Ghana, in August 2007 (MTN Group, 2006, 2008). MTN is currently present in 21 countries in Africa and the Middle East. MTN is presently the largest network provider in Ghana in terms of subscriptions with a mobile voice market share of 45.51 percent in January 2015, recording an increase in subscription from 13.8 million in December 2014 to 13.9 million in January 2015 ( NCA, 2015).

\subsubsection{Vodafone Ghana}

The UK-based Vodafone Group, one of the world's largest mobile telecom companies, entered the Ghanaian market in August 2008 with the acquisition of 70 percent share in the previously state-owned incumbent Ghana Telecom (GT). As part of the sales agreement, Vodafone was expected to facilitate completion of the second phase of the national fibre optic backbone project to cover the entire northern regions of the country (Ministry of Communications, 2011). This would have increased rural access to mobile telephony, e-commerce and e-governance. At the time of the acquisition, GT's mobile brand ONE Touch was the third largest mobile operator in terms of coverage and subscription. Prior to the acquisition, GT's mobile subscription base stood at 1.4 million, equivalent to a mobile market share of approximately 17 percent at the end of March 2008('Vodafone Group, 2008). With the acquisition, the brand name was changed to Vodafone. Vodafone's service revenue in Ghana grew by 19.3 percent in 2014, driven by an increase in customers and higher data usage in both consumer and enterprise(Vodafone Group, 2014). Vodafone Ghana is the second largest network operator with a market share of 23.29 percent in January 2015, representing a subscriber base increased from seven (7) million in December 2014 to 7.1 million in January 2015 (NCA, 2015).

\subsubsection{Millicom Ghana Limited (TIGO)}

Milicom Ghana first introduced mobile telephony into the Ghanaian market in 1992, but lost the ground to Scancom in 1994 when it introduced the digital GSM network. Millicom, a Luxembourg-based company currently has operations in 14 countries in Latin America and Africa. Millicom operates in six (6) African countries ${ }^{2}$ with Ghana being the first country it moved into (Sey, 2008). It started out using the analog ETACS (Extended Total Access Communication System) standard and switched to digital GSM under the brand name Buzz in 2000. The brand name was changed again to TiGo in March 2006 to conform to a global branding strategy (Sey, 2008). In terms of subscription levels, TiGo is currently the third largest network with a market share of 13.7 percent at the end of January 2015 (NCA, 2015). 
Airtel is the fourth largest MNO in Ghana. Bhartil Airtel, an Indian telecoms company, entered the Ghana market in 2010 when it acquired Zain's African operations at a record deal of US\$10.7 billion (Krishnan \& Gokhale, 2010). Celtel International, subsidiary of Zain, had earlier acquired 75 per cent interest in Western Telesystems Ltd (WESTEL), a wholly-owned state telecom company in October 2007 (Amega, 2012). With the acquisition, Zain was rebranded as Airtel. Airtel's market share was 12 percent at the end of January, 2015 (NCA, 2015). Airtel launched its 3.75G service in January 2012, as an upgrade of its 3.5G network to offer improved quality of services to its consumers (GNA, 2012).

Glo mobile, the latest entrant into the Ghanaian mobile industry is a Nigerian-based company. Glo's market share stood at 4.7 percent at the end of January, 2015. Expresso Telecom is a Dubai based operator that acquired the assets of Kasapa Ghana. Expresso is the only MNO using a CDMA network in Ghana, with a market share of 0.39 percent as at end of January, 2015 (NCA, 2015).

In a virtually saturated voice market, six major mobile networks operate in Ghana - Vodafone, MTN, Airtel, Tigo, Glo and Expresso are challenging each other for market share to provide better quality and wider range of services through technological innovations. The current market share of the MNOs is presented in Figure 2

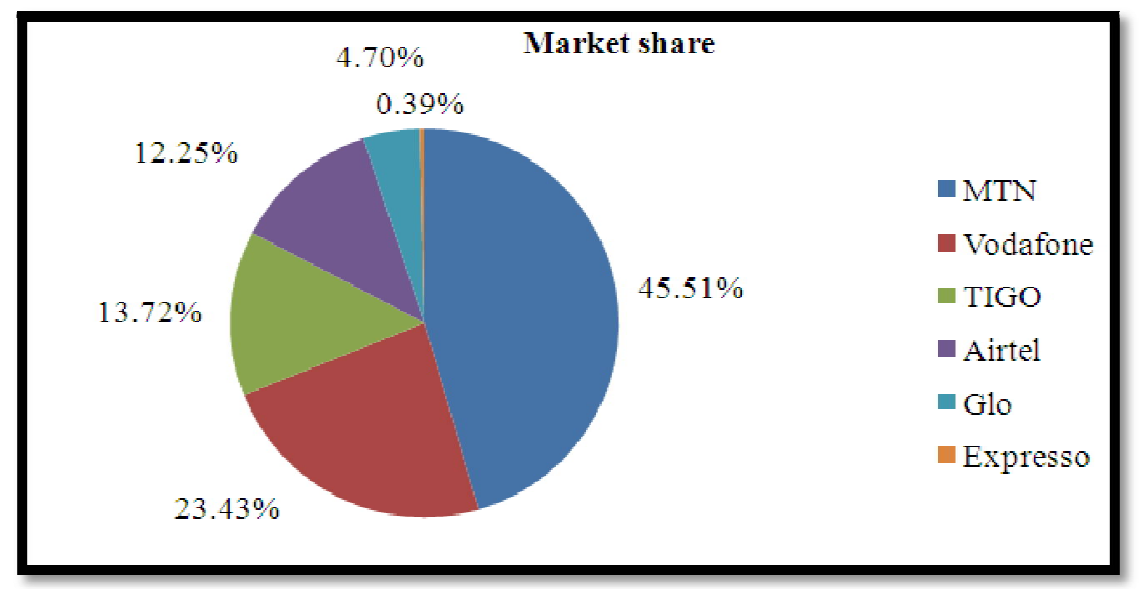

Figure 2: Operators'Market Shares, January 2015 (NCA, 2015)

\subsubsection{Evolution of Mobile Network Operators}

Many MNOs in the market today have a long history in the broader telecommunications industry, and did not start at scratch as MNOs. The US-based AT\&T, for instance, started as a typical telecom company, and provided fixed line telephone services for many decades (Liu, 2010). Also, the Canadian MNO (Rogers Wireless), a subsidiary of Rogers Communications, was a cable service provider in the 1970s and 1980s(Rogers Communications, 2013). These companies were traditionally semi-public telecom conglomerates operating as monopolies on certain resources, with well-established business structures, procedures and systems. With advances in mobile technologies in the 1980s and 1990s, MNOs added mobile communication services into their product portfolios by establishing separate subsidiaries to manage the mobile business (Liu, 2010). With the changing landscape of mobile technologies and devices, MNOs with long history in the telecom industry are required to re-invent themselves and quickly adapt to the mobile service market dynamics by investing in new technical solutions and services so as to reduce cost and increase revenues. More so when other actors like device manufacturers (handsets) and internet companies who offer valued added services and applications to customers have entered the mobile services market traditionally dominated by MNOs (Markendahl, 2011).

Over the last four decades, deregulation, liberalisation and technology innovation have significantly changed the face of the Ghanaian telecommunications landscape. The telecommunications sector reforms began in November 1974, when the National Redemption Council (NRC) Decree No. 311 transformed the state-owned Post and Telecommunication Department into a public corporation, and placed it under the Ministry of Transport and Communications. As at 2007, the Ministry of Communications was still responsible for formulating telecom-related policy, and for the control and regulation of Ghana's telecommunications operations (Osiakwan, 2008).

Then between 1994 and 2004, the country moved from the state-controlled Postal, Telegraph and Telephone (PTT) administration agency model, which hitherto had total monopoly over the very inefficient and obsolete telecommunications infrastructure, to a regime where Internet Service Providers (ISPs) and mobile network operators began to actively compete with the state-owned Incumbent, Ghana Post and Telecommunication Corporation (Osiakwan, 2008). The World Bank funded Accelerated Development Programme (ADP, 1994-2000) formally introduced an era of deregulation and liberalisation in the telecoms sector. Subsequently, the National Communications Act of 1996 (Act, 524) was passed by Parliament leading to establishment of the National Commissions Authority (NCA). Act 524 mandated the NCA to regulate the telecommunications industry so as to ensure efficiency, fair competition and customer satisfaction. The ADP also recommended the demerging of post from telecom and their conversion into limited liability companies (Osiakwan, 2008). This resulted in the formation of Ghana Post and Ghana Telecom as separate entities. With these events taking place at a fast space, the state-controlled monopoly (Ghana Telecom) was compelled to confront new competitors and the market was opened to some amount of competition.

Millicom International Cellular S.A. first introduced mobile phones into the Ghanaian market in 1992 with its Mobitel brand. Millicom, a Luxembourg-based telecommunications company which operates in Latin America, Africa and Asia; and its African brand was first launched in Ghana (Sey, 2008). Millicom began with the analogue ETACS (Extended 
Total Access Communication System) standard. Celtel joined the industry later in 1994 when it launched an analogue AMPS (Advanced Mobile Phone Service) system to cover only parts of Accra and Tema. Then Scancom revolutionised the mobile phone landscape upon entering the market in 1996 with its 2G digital GSM technology and rapidly captured the market (Sey, 2008).

These developments perhaps compelled the government to partially privatised the Incumbent Ghana Telecom (GT) in 1996 by allowing G-Com Limited (a Ghanaian company in which Telekom Malaysia had 85\% interest) to purchase $30 \%$ stake in the company (Osiakwan, 2008). This partially privatisation and injection of capital enabled GT to launch its ONETouch GSM mobile service in 2000. This further opened the floodgate for new entrants into the market. Finally, the Incumbent Ghana Telecom and its mobile subsidiary ONETouch were fully privatised in August 2008 with Vodafone International Holdings B.V., a wholly owned subsidiary of the Vodafone Group taking a 70 per cent stake (Vodafone Group, 2008). There are currently six mobile network operators in the market: Expresso, Millicom (Tigo), Scancom (MTN), GT/ Vodafone Mobile, Airtel Mobile and Glo Mobile.

With six network operators, Ghana's mobile telecommunications sector recorded 30.6 million voice subscriptions at the end of January 2015 from a low of 15 million subscribers in 2009 (NCA, 2015; ITU, 2014b). Mobile coverage has expanded to cover more geographical areas and user adoption continues to increase. Mobile telephone voice and SMS service penetration was as high as 114/ 100 people at the end of January 2015 from a low of 63.7/ 100 persons in 2009. In contrast, fixed-phone subscriptions, which once represented the main telecommunication network coverage was a mere 1.00 percent in January 2015 (NCA, 2015; ITU, 2014b). At the end of January, 2015, the market share of mobile telephony was 99.15 percent (NCA, 2015).

\subsubsection{Operator Objectives and Service Offerings}

The primary objective of mobile network operators was to provide mobile communication services to customers, especially voice mobile services, voice mail and call forwarding. However, as mobile technologies evolved broadband data services are being added to the services menu provided by MNOs (Qualcomm, 2014).Some of these enhanced services include mobile internet access, location-based services, music and movie downloads, ringtone download, mobile money services, device theme download, mobile television and high speed broadband data services. Depending on the market, MNOs have to strategically select the basket of services that are most in demand by their customers (Liu, 2010).

As different MNOs make choices in terms of the basket of services to provide, customers evaluate these services to set the various MNOs apart and as a result to make their purchasing decisions. For example, Vodafone Ghana has a service specifically designed for business users called the "Vodafone Business Solution". It is a Wireless Office facility for small and medium enterprises (SMEs), which allows users to have access to seamless data connection, video and audio conferencing, and make phone and FAX calls via a 3G network. SMEs can connect any analogue phone or FAX and about 30 computers on Wi-Fi (Vodafone Ghana, 2011). The video and audio-conferencing facility allows SMEs to network and have meetings with their colleagues/ partners across Ghana in real-time. Technology driven SMEs will be attracted by the convenience that the service provides and will most likely select Vodafone Ghana as their service provider. Liu (2010:24) has noted that the competition is MNOs are more in the service field rather than in the technology field. In other words, MNOs are using the variety of services they offer to entice and win subscribers.

Faced with a number of challenges in the market, some MNOs try to compliment the services by offering mobile devices to their subscribers. In this case, they are also playing a similar role like retailers. MNOs strategically select mobile handsets and devices that will best deliver the services they provide so that subscribers can get the most out of these services. Mobile devices that MNOs often offer include low cost phones, smartphones, notebooks, and netbooks ${ }^{3}$. Usually, the MNOs obtain these devices directly from the Original Equipment Manufacturers (OEMs) and bundle them as part of their service packages. Selling a bundle at an attractive price, especially in low income countries, can attract new customers and reduce churn (the proportion of customers that leave the network).

In addition to providing quality services to attract and retain customers, the other key objective of MNOs is to maximise the average revenue per user (ARPU). One way to achieve this goal is to expand into new markets. For instance, though low-cost phone markets may have slim margin, they offer excellent potential opportunities for growth, particularly in emerging low-income countries ( $\mathrm{Liu}, 2010$ ).

MNOs everywhere in the world either provide post-paid or prepaid payment plans to their customers. Prepaid payment plans are usually designed for subscribers who do not want to have any contract with the network operator. Subscribers are required to buy pre-paid credit for calls, SMS and mobile data and replenish them when needed. While this pre-paid concept known as Pay-As-You-Go (PAYG) provide subscribers the flexibility and freedom to manage their cash flows, to the MNOs prepaid plans offer irregular flow of revenue. Prepaid plans do not generate a regular and stable flow of revenue from subscribers, hence the ARPU of prepaid plans are often lower compared with post-paid plans. This explains why most MNOs tend to design various post-paid packages for their subscribers. With post-paid plans, subscribers are expected to agree to a contract with the MNOs and commit to agreed terms of payment. In order to motivate subscribers to sign unto post-paid plans, MNOs usually provide some discount to post-paid and handset bundle plans, and this is a very attractive way to generate subscriber loyalty (Liu, 2010). 


\subsubsection{MNO Capabilities}

Liu (2010) has noted that the ability to acquire and to retain customers by developing and operating an efficient mobile network is the core competence and capability required of MNOs. Hence, the ability to perform this key network operation capability is what differentiates a mobile network operator from other actors in the field.

From a regulatory point of view it is worthwhile to note that a substantial proportion of subscribers cancelled their MNO contract in a spirit of "prevention" just to ensure that they do not miss a contractual termination deadline(Gerpott, Ahmadi, \& Weimar, 2015). Gerpott and his group (2015) also believe that; Knowledge concerning differences in contract, socio-demographic and service use characteristics as well as in stated reasons for quitting between "termination withdrawers" and "termination stickers" are valuable because it makes better allocation of their limited resources.

In this sense, network development capabilities include expanding networks to new under-served areas such as rural and smaller communities; managing network technology migration (e.g. from $2 \mathrm{G}$, to 3G, to 4G LTE, etc.); developing and deploying network technologies to support new applications on the network such as VoIP, mobile TV, and mobile data; and maintaining quality of services as more customers subscribe to the network. The added value of having an efficient and well operated mobile network is that valuable services can be provided to customers thus creating more business for the MNO (Liu, 2010:25).

\subsubsection{MNO Market Growth}

The MNO sub-sector is growing at a very fast pace and increasingly becoming more sophisticated like the larger mobile telecoms industry. The global mobile voice market is levelling up. In 2014, global growth in mobile penetration was estimated at a ten-year low of 2.6 per cent, as the market reaches saturation in many developed countries (ITU, 2014a). However, Africa and Asia, and the Pacific regions, which have the lowest penetration rates have the huge potential for mobile growth, estimated at 69 per cent and 89 per cent respectively as at the end of 2014 (ITU, 2014a; GSMA, 2014a). The market value of the mobile network operators is also expanding in a highly competitive environment, particularly with the arrival of new entrants like Apple and Google. Again, this growth is fuelled by increasing demand for voice and mobile data services in emerging markets(Markendahl, 2011). Despite the stagnation of mobile voice communication, voice services in emerging markets are predicted to remain a major revenue stream in the future and contribute about 85-95 percent of the mobile operators' total revenue ${ }^{4}$. On the other hand, the revenue margin for mobile data though also declining remains high. However, MNOs must innovative by launching high value applications and other high-quality data services that have high revenue per bit to keep data revenue growth profitable. This will also enable MNOs to attract and retain customers.

\subsubsection{Equipment Manufacturers (Infrastructure and Handset)}

Generally, MNOs operate in close cooperation with several other network parties. On one hand, mobile handset manufacturers such as Samsung, Alcatel, Ericsson and Nokia have to cooperate with MNOs to guarantee their support and facilitate sales through the mobile operator, in addition to the apparent sales channel established by dealers. On the other hand, MNOs need to work collaboratively with both these equipment and handset manufacturers (e.g. Alcatel, Ericsson, Huawei and Nokia) towards a better telecommunications infrastructure that would enable them to offer quality service to the changing mobile data environment and to increase coverage to new customers. It is important to note that equipment and handset manufacturers play pivotal roles in setting mobile technology standards.

In addition to the above outlined and rather evident actors, it should be noted that in the mobile industry the role of standard-setting organizations such as 3rd Generation Partnership Project (3GPP) and the International Telecommunications Union (ITU) is of great importance. This is due to the fact that standards are co-developed among industry leaders (Nokia, Samsung, Apple, Ericsson, Huawei, Motorola etc.) and the companies that manage to include their Intellectual Property Rights (IPRs) into the final standards such as 3GPP Release 99 (i.e. the base case standard for 3G devices and networks), have a significant advantage over other manufacturers due to license payments (Husso, 2011).

\section{Mergers and Acquisitions}

\subsection{Introduction}

Mergers and acquisitions (M\&A) have long been a popular growth strategy that companies adopt for different reasons and motives. Hence, an extensive body of literature exists explaining why firms decide to get involved in M\&A activity. One of such motives is technological innovation and deployment, which has become an increasingly important source of value creation in many high-technology industries like the mobile telecoms sector(Hitt et al., 2009).This chapter will present a brief overview of merger and acquisition activities. First, M\&A concepts are defined, followed by a classification (topology) of mergers and acquisitions, and then an overview of M\&As in the telecommunications industry from a global perspective is provided. Next, the theory in which M\&A influence on new technology value creation is founded is presented - by describing briefly the theoretical explanations for M\&A as evident in the literature. Finally, the literature on M\&A reasons and motives are discussed.

\subsection{M\&A Definitions and Concepts}

The term "mergers and acquisitions" (M\&A) is often used to describe various corporate restructuring strategies, but the words really refer to different types of business activities (Baca, 2015). In the strictest sense, the words 'merger' 
and 'acquisition' mean two different things. A merger means that two companies present the willingness to combine their activities and organize a common control of their assets ( Sachwald, 2001, cited in Aggoud, \& Bourgeois, 2012). In other words, a merger is 'the unification of two or more firms into a new one' (Straub, 2007). An 'acquisition' on the other hand, is an indication that a firm presents the willingness to buy another one (Sachwald, 2001, cited in Aggoud and Bourgeois, 2012). An acquisition thus represents 'one company's purchase of the majority of the shares from another' (Bresslmer et al. 1989, Pausenberger 1990, Brauchlin 1990, cited in Straub 2007:15). The difference between a merger and an acquisition is that, after a merger, the result of the unification leads to the existence of fewer firms than before the operation, and the acquired firm or firms cease to exist (Straub, 2007). In the case of an acquisition, the target firm can still remain autonomous; it can also be partially or completely integrated into the acquiring company after the acquisition activity (Straub, 2007). Straub (2007) has noted that mergers and acquisitions represent, in a legal point of view, different transactions.

In general terms, a merger or acquisition is a transaction where two or more companies are combined to become one ( Weston and Copeland, 1992, cited in Van Frederikslust et al., 2005). A merger is a transaction between more or less equal partners, while acquisitions are used to describe a transaction where a substantially bigger company (the bidder) takes over a smaller company (the target). In this study, no distinction is made between mergers and acquisitions and the two concepts are used interchangeably in their broadest sense. As a result, the study adopts the definition provided by Kootz (1996, cited in Straub, 2007:16) as "all forms of inter-industrial relationship and cooperative activities involving the purchase or exchange of equity stakes".

\subsection{Classification of Mergers and Acquisitions}

Generally, Mergers and Acquisitions are classified in different many ways, for this study, the classification used by economist which classify mergers into four categories is discussed. These are horizontal, vertical, conglomerate and congeneric M\&As(Amega, 2012; Gaughan, 2007). Horizontal mergers and acquisitions take place when two companies that are present in the same sector of activities combine their assets. In this case, the companies are usually direct competitors in the same industry (Gaughan, 2007). A classic example in the telecommunications industry is the merger between Vodafone and AirTouch USA in 1999. The main motive of horizontal M\&A activity is usually to reinforce and improve the competitive position of the company. Certainly, the company stands to gain, for instance, from the economies of scale due to the increase of its size and increase in its market shares and/ or its product line (Aggoud and Bourgeois, 2012; Straub, 2007). The size effect could also contribute to increase the company's power of negotiation with its customers and suppliers (Leroy, 2003, cited in Aggoud and Bourgeois, 2012). Gaughan (2007) has noted that in a situation where a horizontal merger has the tendency to cause the combined firm to experience an increase in market dominance which will have anti-competitive effects, then regulators may oppose the merger on antitrust grounds.

Vertical mergers and acquisitions refer to the acquisition or merger of a firm with another company with which the acquiring firm has a customer or a supplier relationship (Cameron, , \& Green, 2009). In other words, the process involves a firm taking control of another company or companies that are either upstream or downstream in the value chain (Leroy, 2003, cited in (Aggoud, \& Bourgeois, 2012). Vertical M\&A activity enables companies to reduce transaction costs and the number of intermediaries, ensures a dependable source of supply, the ability to demand specialized supply, and improved competitive position of the combined firm (Cameron, \& Green, 2009). Thus, this allows the combined company to benefit from economies of scale as well as having an advantage over competitors (Aggoud, \& Bourgeois, 2012). In most cases, firms increase their market power by controlling the distribution channels and access to raw materials. A good example of a vertical merger is when internet provider America Online combined with media conglomerate Time Warner in 2000 (Baca, 2015). The merger is considered a vertical one because Time Warner supplied content to consumers through properties like CNN and Time Magazine, while AOL distributed such information via its internet service (Baca, 2015).

Conglomerate M\&A activities take place when two or more companies without common business decide to pool resources for some other reason. A firm acquires or merges with another company, which is 'neither a competitor, nor a buyer, nor a seller' (Cameron and Green, 2009:224). Under this arrangement, companies have different activities and are not present in the same businesses. The main motive for this activity may be to diversify and reduce the risk linked to changing economic conditions (Aggoud and Bourgeois, 2012). An example is when Procter and Gamble, a consumer goods company, merged with Gillette in 2005. At the time, Procter and Gamble was largely absent from the men's personal care market, a sector which was dominated by Gillette. With the two companies' having complementary product portfolios, the merger created one of the world's biggest consumer product conglomerates (Baca, 2015). Another example is when Philip Morris, a tobacco company, acquired General Foods in 1985, Kraft in 1988, and Nabisco in 2000 (Cameron and Green, 2009). Congeneric Mergers take place where two companies in the same or related industries but do not offer the same products merge together. Here the companies may share similar distribution channels, providing synergies for the merger or related by technology, markets, or production processes. A good example of congeneric merger is Citigroup's acquisition of Travellers Insurance, both companies were in the financial services industry, but had different product lines. The acquired firm is either an extension of a product line or a market related to the acquiring firm. (Kehinde and Abata, 2010).

In addition to the four categories discussed above, Straub (2007:17) described concentric mergers and acquisitions as situations where the parties involved intend to pool their collective "know-how potentials such as their production technology, distribution system, or research and development (R\&D) capacities". In a concentric merger activity, the firms can combined their strengths in such a way as to create new core competencies or complement ones already in existence (Straub, 2007).

In terms of geographical coverage, M\&A activities can also be classified as either cross-border or domestic (national). Chen and Findlay (2003:15) defined cross-border M\&A as 'any transactions in assets of two firms belonging to 
two different economies'. This definition suggests that the companies are not located in the same economies, or the operation takes place within the same economy but with firms from different countries (Chen \& Findlay, 2003). Regarding domestic mergers and acquisitions, the firms involved are located in one country and operate in its domestic market (Chen and Findlay, 2003).

An M\&A activity could also be described as either a friendly or hostile offer. The deal offer is term friendly when the acquiring firm contacts the target's management and negotiates with them the conditions of the deal they are making. Most of the transactions are completed during friendly negotiations with the company's board and executives (Chen and Findlay, 2003). Some tender offers are hostile in situations where an offer is made directly to the shareholders without the approval of the target's board of directors. This may be the case, when the friendly tender offer was earlier rejected by the target's management (Zielinska, 2004).

In summary, the classification of the different types of mergers and acquisitions as presented in this section of the review is important in order to put the motivations behind these activities in context. In the next section, an explanation of the reasons why companies want to be involved in M\&A activities will be presented.

\subsection{Mergers and Acquisitions in the Telecommunications Industry}

The wave of M\&A in the world telecommunications market in the 1980s and 1990s was triggered primarily by the deregulatory and liberalisation reforms of the industry that were introduced worldwide ( Park et al., 2002). These reforms, particularly in the USA and Europe, opened the market for fierce competition and technological innovations, resulting in falling profits of traditional operators in the telecommunications service markets. This further accelerated the wave of M\&A in the economically developed countries (Hsu \& Chen, 2006).

Consequently, the early 1990s witnessed a series of cross-border M\&A involving leading telecommunications industry operators across the world such as the classic example of the Vodafone and AirTouch merger in 1999. This particular merger between the UK-based Vodafone and US-based AirTouch created the world's largest mobile telecommunications company at the time with a combined market capital of about $€ 77$ billion (US\$122 billion), with the new company having operations in 23 countries ( Cheyne and Hayes, 1999). On reasons for the merger, the parties noted that globalisation created significant potential for telecommunications providers who were capable of reaching across borders and customer groups. Thus, the ability to leverage scale and scope provides global operators with significant operating efficiencies and revenue advantages ("Vodafone Group, 1999). This confirmed the assertion that firms have tended to use M\&A to build competitive advantages in the world market through combinations with other firms (Zielinska, 2004). Chan-Olmsted and Jamison (2001) have earlier argued that, with deregulation and liberalisation beginning in the 1980s, the form of competition in the global telecommunications industry seems to have been largely market-driven ostensibly aimed at gaining competitive advantages through strategic combination of resources and presence in multiple products and geographic locations.

Much of the cross-border M\&A that took place during the 1990s were in the USA and Europe and not very much in Asia and Africa. However, from 2000 onwards some telecommunications firms in Asia and Africa initiated M\&As to extend their market power regionally (Park et al., 2002). For example, Singapore Telecom acquired Hong Kong Telecom in 2000 to enable the new company play a major role in the Asian market. Africa recorded its biggest M\&A deal between telecom firms in 2010, of a capital value of US\$10.7 billion, when Indian telecommunications group Bharti Airtel acquired Zain's African operations. This particular takeover displayed, some crucial features found in most telecom mergers elsewhere in the world, which is the excessive financial amount involved, mostly financed by stock exchange and other capital markets (Zielinska, 2004). The reasons for theM\&A wave in Africa are not different from motives for M\&A elsewhere. Improved economic growth and investment climate on the continent, rapid technological innovation and convergence, deregulation and privatization of national monopolies and financial marketincentives have been cited for the trend ( African Development Bank [AfDB], 2012; Le Blanc and Shelanski, 2002.).

\subsection{Theories of Mergers and Acquisitions}

The aim of this section is to provide a short review of the literature on the underlying theories regarding the reasons and motives for mergers and acquisition activities. First, the two main theories used to describe the reasons and motives for M\&A: value creation and redistribution theories will be described. This will be followed by an explanation of some of the reasons and motives for mergers and acquisition.

\subsubsection{Value Creation Theories}

The value creation theories posit that mergers and acquisitions make economic sense if the whole is worth more than the sum of its parts, in other words if synergy exists ( Van Frederikslust et al., 2005)value can be achieved through: economies of scale in production and distribution, access to new markets, having a combined office, removal of inefficient management, greater financial possibilities and combined immaterial assets such as patents, trademarks and licenses (Van Frederikslust et al., 2005:3). Vertical mergers reduce the industrial chain and savings can be made in procurement, more efficient communication strategy as well as ensuring that production is more focused on market dynamics (Van Frederikslust et al., 2005). Barney (1988) notes that the potential synergy gains accruing in related acquisitions may be priced out during negotiations, thus making value creation in horizontal mergers really difficult to achieve. A merger has beneficial impact when the synergy (surplus value) exceeds the incurred merger costs including the takeover premium (Barney, 1988). On the contrary, other scholars (Healy et al., 1990) have found positive results and concluded that in the post-merger phase there are significant improvements in the cash flows compared to other corporations in the industry. 


\subsubsection{Redistribution Theories}

The redistribution theories maintain that a merger has no value if the additional cash flow is lower than the takeover premium and/ or is lower than the costs incurred as a result of the integration (Van Frederikslust et al., 2005; Barney, 1988). There are two major theories that explain the origin of merger activity - the hubris and the agency theory. The hubris theory states that management strives for synergy with the goal of maximizing profits for shareholders. Regrettably, managers may suffer conceit resulting in less value gained in the form of synergy. Roll (1986) has found evidence to suggest that synergetic benefits are achieved in these mergers; however, the pre-calculation of synergy is often too high to justify the takeover premium.

On the other hand, the agency theory holds that the interests of the shareholders or owners are not consonance with the interests of management. The separation of capital and control is an incentive for managers to strive for their own interests. In this case, a reason for a merger may be 'Empire Building', where managers strive to expand the size of the company (Mueller \& Yurtoglu, 2007). For instance, a big global company gives more status and managerial salary is positively related to the size of the company. Similarly, a large firm offers possibilities for enhanced emoluments, and management failures of the past are easier to conceal (Van Frederikslust et al., 2005). Part of the agency theory is the theory of free cash flow. Free cash flow is that part of equity for which there are no profitable investments in the organization. These cash flows, which are generally found in the (free) reserves, could be distributed to the shareholders as dividends (Van Frederikslust et al., 2005). Rather, according to the agency theory, the free reserves are often used to fund merger activities that serve the interests of management and not shareholders. Invariably, the conclusion of a merger seldom leads to an improvement in the cash flow of the involved corporations (Morck, Schleifer and Vishny, 1990).

\subsection{Motives for Mergers and Acquisitions}

The literature abounds with a plethora of reasons and motives for mergers and acquisitions (see Long, 2015; Cameron and Green, 2009; Motis, 2007; Shimizu et al., 2004). However, this section will discuss five of the oft cited reasons, with particular emphasis on the technology adoption motive. These are economies of scale, reducing excess capacity, financing/ agency considerations, technology investments and expansion.

\subsubsection{Economies of Scale}

Achieving economies of scale is an often cited motive for M\&A deal among negotiating companies and therefore a well-known reason for mergers and acquisitions in all industries ( Motis, 2007). Jensen and Ruback (1983) in an overview of the scientific evidence noted synergies as one of the gains achieved from takeovers. Similarly, Agostini et al. (2012:12) also found significant economies of scale in operating costs of merged companies in the pension fund market in Chile. Gaughan (2007) has noted that merger managers tend to cite cost-saving operating synergies such as economies of scale as the main source of operating synergies.

Reducing production cost enabled a combined firm to harness the potential benefits of efficiencies through network expansion. These operational efficiencies may accrue from economies of scale, production economies of scope, consumption economies of scope, improved resource allocation, moving to an alternative less costly production technology or asset configuration, and improved use of information and expertise (Gattoufi, Al-Muharrami and Al-Kiyumi, 2009; Majumdar et al., 2006, 2009). Majumdar et al. (2009) have noted other efficiency considerations for M\&A include improved focus on core skills and competencies of the firm, a more effective combination of assets, improvements in the use of brand name capital, and reductions in transaction costs. Thus, mergers or acquisitions could then be seen as the quickest, cheapest, or only way to achieve these benefits. For instance, in the telecoms sectors savings from access charges can form a major cost savings for common carriers in the industry( Majumdar et al., 2009). The cost saving and efficiency motivations are based on the fundamental value creation theories of M\&A, which posit that there is a positive gain to both acquirer and target (Gattoufi et al., 2009).It has also been argued that M\&A lead to improve financial efficiencies, as firms may diversify their earnings by acquiring other firms or their assets with dissimilar earnings streams (Majumdar et al., 2006; Long, 2015).

\subsection{2 .Excess Capacity}

Reducing excess capacity is generally considered as an industry level characteristic that motivate some merger activities. Excess capacity can be in the form of redundant capabilities or obsolete technologies and capital equipment that should be discarded to reduce operations costs. For example, when Vodafone took over GT in 2008, the new company reduced its staff strength by 1,331, and at the same time recruited more than 350 Ghanaians with various expertise into new roles and responsibilities (Vodafone Group, 2010).

\subsubsection{Financing/Agency Issues}

In the past a large portion of mergers and acquisitions were financed by cash. Despite that this trend has decreased considerably in the 1990's, the financing for most M\&A still includes partial cash payments (Weston et al., 2005, cited in Sherif, 2012; Andrade, 2001). Jensen et al. (1986) proposed, based on the theory of free cash flow, that managers with large cash flows were more likely to undertake value destroying mergers. The underlying principle supporting this theory is that managers with low expected growth and few investment opportunities will tend to invest the cash flow in unprofitable projects. Consistent with this theory, Verde (2008) in a study on mergers and acquisitions in the European energy sector suggested that the extra cash that energy companies have accumulated is used in M\&A to the detriment of longer-term strategic investments in areas such as generation, transmission or exploration. Verde (2008) then 
hypothesized that this trend is as a result of the "short-termism" investment decisions, favouring a lowest-risk and lowestuncertainty strategy.

\subsubsection{Technology Investments}

The need to deploy new technologies also influences M\&A activity. Goldman, Gotts and Piaskoski (2003) have reported that the provision of broadband access services for consumer use at home and the ability to combine content with transmission were key factors behind many telecommunications mergers in the USA. This explains why network assets and technical abilities have been cited as another primary motivation for acquisitions by larger and more stable carriers seeking to expand their networks (Majumdar et al., 2009). Such acquisitions aim to integrate the network infrastructure and content of the merging companies in addition to enhance the ability to innovate improved infrastructure. For instance, Vodafone in acquiring AirTouch USA argued that the combined company will be very well positioned for the next phase of growth in mobile communications through the development of $3 \mathrm{G}$ next generation services (Vodafone Group, 1999).

These oft cited reasons notwithstanding, the literature on the technology adoption effects of M\&A is inconclusive. Proponents have argued that M\&A may build up competencies and foster innovation for some reasons such as reducing high transaction costs related to the transmission of knowledge between firms ( Bresman et al., 1999). Also, in fast moving and emerging markets, firms may perceive that they do not have the time to develop the required skills and knowledge internally, and as a result M\&A may offer a quick access to knowledge assets (Warner et al., 2006). Moreover, M\&A may extend the technological base of firms involved thus allowing them space to achieve greater economies of scale and scope through more efficient deployment of knowledge resources. Furthermore, M\&A may enlarge the overall RandD budget of firms involved, which then enables them to tackle advanced technological deployments and, thereby spreading the risk associated with innovation (Gantumur and Stephan, 2007). In addition, the integration of complementary knowledge may also increase innovation through M\&A leading to more advanced technologies being developed (Gerpott, 1995, cited in Gantumur and Stephan, 2007). Hagedoorn and Duysters (2002) have reported that M\&As can contribute to improving the technological performance of companies in a high-tech environment like the mobile telecoms sector, but that both the organisational and the strategic fit of the companies involved in these M\&As are crucial for the technological success of M\&As.

In contrast, it has been found that differences in corporate culture, processes and knowledge base may impede a smooth transfer of knowledge in an innovation-driven M\&A activity (Lane, \& Lubatkin, 1998; Very, 1997 ). It has to be noted that M\&A integration process is time consuming and costly and may be influenced by other factors other than preM\&A intentions. Later events such as market forces may divert management attention away from innovation (Hitt et al., 1996, cited in Gantumur and Stephan, 2007). Also, trade off payment of debt and debt costs for investment in RandD can occur due to M\&A ( Hitt et al., 1990). In some cases, it will be disadvantageous if the M\&A activity involves entire firms whereas the advantages for knowledge exchange may be limited to only a small part of the firms involved. In M\&A, knowledge beyond that required is acquired as well. As a result, a firm may acquire more knowledge than it can effectively utilise (Hennart and Reddy, 1997). The literature has shown that technology motivated acquisitions are very risky and prone to failure (Bannert \& Tschirky, 2004; Chakrabarti et al., 1994). One of the key reasons for this value destruction has to do with the inappropriate integration of the technology-based firm after the acquisition ( Hagedoorn and Duysters, 2002).

Having given both sides of the coin, GSMA (2014c) in a recent report, found that mobile telecom companies' mergers increased investment and Quality of Service (QoS) by creating incentives such as a larger customer base that leads to economies of scale, and the ability to differentiate from competitors if the merger results in a superior spectrum holding. The report stated that European and American competition authorities' concerns that mobile mergers have the tendency to create oligopoly markets to the detriment of consumers are often overstated. Rather, mergers can accelerate the transition between technology cycles in the mobile industry, which are responsible for most reductions in unit prices, as well as improvements in quality and service innovation. "Mergers can be a catalyst for driving higher levels of network investment which result in improvements in quality, innovation and, ultimately, lower prices (GSMA, 2014c:7).

\subsubsection{Market Expansion}

Traditional production-based theories contend that the primary motivations for mergers are the acquisition of market power and the achievement of economies of scale. In combining assets and customers, firms hope to create market power by eliminating actual competition or potential competition (Goldman et al., 2003). Stigler (1950, cited in Mujumdar et al., 2006) had argued several years ago that market expansion might have been the cardinal motivation for many of the mergers and acquisitions during the last quarter of the nineteenth century and the first half of the 20th century. Stigler called the 1887-1904 merger wave "mergers for monopoly" and the 1916-1929 wave "mergers for oligopoly." Regardless of whether market power was, or was not, a major motivation for mergers in the first-half of the century, it cannot be ruled out that the bulk of more recent merger activity could be attributed to an effort to secure market control (Majumdar et al., 2006). 


\section{Research Methodology}

\subsection{Introduction}

This section describes the methodology which has been adopted for this study. The case study method was adopted because it is related to the purpose of the study. The section will present the methodological approach, the research design, data collection and analysis.

\subsection{Methodology}

Methodology is an explicit way of structuring one's thinking and actions in terms of research. According to Strauss and Corbin (1998:3, cited in Taber, 2013), methodology is a "way of thinking about and studying social reality". In other words, methodology is the strategy used to adequately answer the research questions, and has been described as "a theory of how inquiry should proceed" (Schwandt, 2001:110, cited in Taber, 2013). Methodology enables readers to logically follow and understand the vision of the researcher and the purpose for conducting the research (Strauss and Corbin, 1998).

Traditionally, there are two main research methodologies, which are quantitative and qualitative. Aliaga and Gunderson (2002) succinctly described quantitative research as explaining phenomena by collecting numerical data that are analysed using mathematically based methods such as statistics. On the other hand, qualitative research is any type of research that produces findings not arrived at by statistical procedures or the means of quantification (Strauss and Corbin, 1998, cited in Lapan, Quartaroli and Riemer, 2011). Creswell (2007:37) defines qualitative research as "the study of research problems inquiring into the meaning individuals or groups ascribe to a social or human problem". It is an inquiry process of understanding a social or human problem, based on the collection of data in a natural setting sensitive to the people and places under study, and data analysis is inductive. This suggests that qualitative researchers "study things in their natural settings, attempting to make sense of or interpret phenomena in terms of the meanings people bring to them"( Denzin and Lincoln, 2005:2, cited in Creswell, 2007).

In fact, qualitative research involves the studied use and collection of a variety of empirical case study data, personal experiences, life story interviews, observational, historical, interactional, and visual texts-that describe routine and problematic moments and meaning in individuals' lives (Morgan, 2007; Denzin and Lincoln, 1994:). Consequently, it allows the study of persons' lives, lived experiences, behaviours, as well as the functioning of some organizations and social movements (Strauss and Corbin, 1998). In addition, the qualitative approach allows the researcher to have more freedom in collecting data and information (Arbnor and Bjerke, 2009).

\subsection{Research Design}

Bhattacherjee (2012:38) defines research design as a "comprehensive plan for data collection in an empirical research project". All the processes involved in planning and conducting the research from problem identification, data collection and analysis constitute the research design (Bhattacherjee, 2012; De Vaus, 2001; Babbie, 1992). According to De Vaus (2001:9) the function of the research design is to ensure that the evidence obtained enables the researcher to answer the research questions as unambiguously as possible. A good research design ensures that the purpose of social scientific inquiry, which is to explore, describe or explain social phenomena, is adequately fulfilled. Exploratory research design may be used to examine new interest or when the field of study is relatively new or unfamiliar to the researcher. It could also be employed to identify key issues and key variables for further inquiry. On the other hand, the purpose of descriptive research is to provide an accurate description of observations of phenomena, while explanatory studies look for explanations of the nature of certain relationships, usually through testing hypothesis so as to provide an understanding of the relationships that exist between variables (De Vaus, 2001; Babbie, 1992).

\subsubsection{Case Study Design}

The case study is "an empirical inquiry that investigates a contemporary phenomenon within its real-life context, especially when the boundaries between phenomenon and context are not clearly evident" (Yin, 2003:13). Since the case study design is conducted in a natural setting with the intention to comprehend the nature of current processes in a previously little-studied area (Benbasat, Goldstein, and Mead, 1987), it allows the researcher to grasp a holistic understanding of the phenomenon under investigation (Creswell, 2003; Eisenhardt, 1989). Rather than seeking answers to questions such as "how much" or "how many," a case study design is useful for answering questions on the "how" and "why" of social phenomena (Benbasat et al., 1987; Yin, 2003). According to Orlikowski and Baroudi (1991), in the information systems research field, case study has demonstrated its appropriateness to generate a well-founded interpretive comprehension of human/technology interaction in the natural social setting. Consequently, from an interpretive perspective, the researcher can obtain sufficient material from the selected case(s) for subsequent analysis (Miles and Huberman, 1994).

This study adopted the qualitative case study design as the main objective of the research is to explore the influence of mergers and acquisitions on new technology deployment in the Ghanaian telecom's context. As Baxter and Jack (2008) explained, qualitative case study design facilitates the exploration of phenomena within its context using a variety of data sources. Thus, the case study design allowed the researchers to conduct an in-depth analysis of the issues regarding mergers and acquisitions in the Ghanaian telecoms sector and how these have influenced network operators' ability to deploy new technologies. Furthermore, the qualitative case study approach allowed the researchers to have more freedom in collecting data and information (Arbnor and Bjerke, 2009), using a variety of data sources. 
Creswell (2003:15) describes a case study as where the "researcher explores in depth a program, an event, an activity, a process, or one or more individuals", by collecting detailed information using a variety of data collection procedures. The case study can be either a single-case or multiple-case design depending on the number of individual cases to be analyzed (Yin, 2009; Larsson, 1993). Creswell (2007) suggests that the structure of a case study should be the problem, the context, the issues, and the lessons learned. The data collection for a case study is extensive and draws from multiple sources such as participant observations, interviews, archival records or documents, and audio-visual materials (Hancock and Algozzine, 2006). Hence, adopting a case study allows for great flexibility and more in-depth analysis of the unfolding phenomena under investigation. Also, the study adopted a multiple case approach involving two telecom companies as this allows for obtaining more generable results than a single case. In fact, it is more appropriate as it allows for more robust conclusions and the analytical benefit to be derived could be more substantial (Yin, 2003).

The case study presented in this study follows a multiple case (two telecom companies) design employing mainly qualitative data sources. The case study is supported by analysis of the Ghanaian mobile telephony landscape presented in Chapter two (2). A chronological presentation of the case study and its link to preceding and subsequent parts of this paper are illustrated in Figure 3

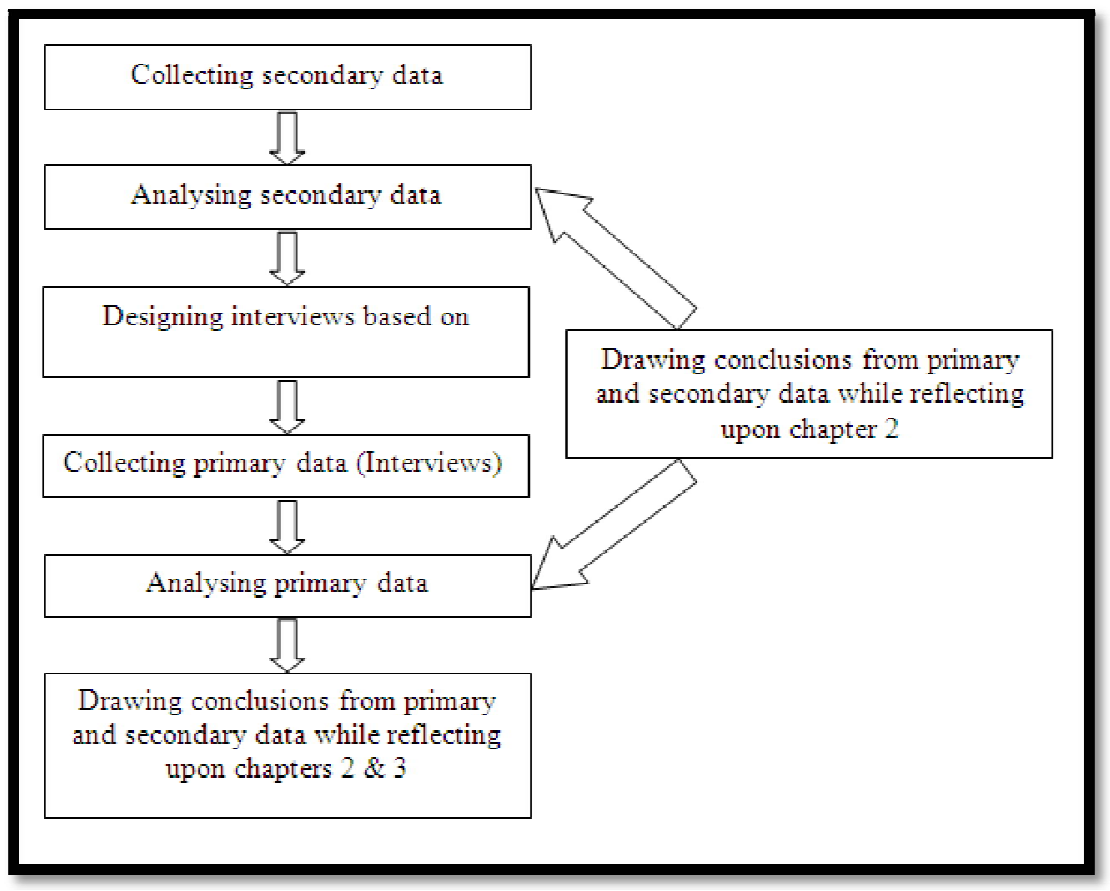

Figure 3: Chronological Presentation of Case Study

\subsubsection{Selection of cases}

Two mobile network operators - Vodafone Ghana and Airtel - have been purposively selected as cases for the study. Vodafone Ghana was selected because it represented the acquisition of an Incumbent that was performing poorly due to obsolete equipment and managerial inefficiencies, in the midst of fierce competition following liberalisation of the Ghana telecoms sector in the 1990s. It is therefore important to find out how the company has benefitted from the acquisition by the Vodafone Group, a leading giant in the global mobile communications industry. Zain (a new entrant) was also acquired by Airtel as part of Airtel acquisition of Zain's African operations. Hence, it is important to find out how this take over has bolstered the company's technological deployment, innovations and competitive edge. For an overview of the case study companies see section 3.3.1.

\subsection{Data Collection}

The main data collection method used to analyse the influence of Mergers \&Acquisitions as providing incentives for new technology deployment by the case study telecom companies was secondary data from public sources such as company reports, other industry players' publications, news releases and news reports. This was to be supplemented by self-administered questionnaires with single key informant from each of the case study companies' and the National Communications Authority (NCA), the industry regulator in Ghana. It was a requirement that each respondent had to be knowledgeable about the company and its competitive environment, as well as the technological developments following the acquisition. The methodological justification in using a single respondent approach is to find the most appropriate respondent (John and Reves, 1982). Thus, we qualified our respondents as individuals who held a Corporate Services Executive (CSE) or equivalent position and was very familiar with the acquisition processes.

The data collection for the case study is designed in a way that the observed explanations for the technology deployment and product innovations by the two companies are mapped through triangulation of several secondary data sources, which was to be supplemented by selected key informants. 


\subsubsection{Secondary Data Sources}

The secondary data collected for the case study consists of selected company annual reports, company policy publications, other industry players' publications, news releases and news media reports in archival form. The specific data sources among these were selected on the basis that they represented both materials provided by the companies themselves and parties that can be considered reliable. The sources for Vodafone were selected such to cover the period from August 2008 when the company entered the market to present. In the case of Airtel Ghana, the sources were selected from July 2010 to date. An example of the secondary data sources is given in Table 2. The full list of all the data gathered from secondary sources for the study is shown in Appendix 1.

\begin{tabular}{|c|c|c|c|c|c|c|}
\hline$\#$ & Type & Date & Source & Title & The Issue & Whose Opinion \\
\hline 1 & $\begin{array}{l}\text { News } \\
\text { article }\end{array}$ & 03/07/ 08 & REUTERS & $\begin{array}{c}\text { Vodafone acquires } \\
\text { 70pct stake in } \\
\text { Ghana Telecom }\end{array}$ & $\begin{array}{l}\text { Announces } \\
\text { Vodafone's } \\
\text { agreement to } \\
\text { acquire GT }\end{array}$ & $\begin{array}{l}\text { Arun Sarin, } \\
\text { Vodafone's Chief } \\
\text { Executive }\end{array}$ \\
\hline 2. & $\begin{array}{c}\text { News } \\
\text { Release }\end{array}$ & $03 / 08 / 08$ & $\begin{array}{l}\text { Vodafone } \\
\text { Group } \\
\text { Releases }\end{array}$ & $\begin{array}{l}\text { Acquisition of a } \\
70 \% \text { stake in } \\
\text { Ghana Telecom }\end{array}$ & $\begin{array}{l}\text { GT takeover } \\
\text { announced }\end{array}$ & - do- \\
\hline 3 & $\begin{array}{l}\text { News } \\
\text { article }\end{array}$ & $15 / 08 / 08$ & $\begin{array}{l}\text { PANA Press } \\
\text { News }\end{array}$ & $\begin{array}{c}\text { Parliament ratifies } \\
\text { sale of Ghana } \\
\text { Telecoms to } \\
\text { Vodafone }\end{array}$ & $\begin{array}{l}\text { Parliament gives } \\
\text { legal backing to GT } \\
\text { sale }\end{array}$ & $\begin{array}{l}\text { Parliament of } \\
\text { Ghana }\end{array}$ \\
\hline 4 & $\begin{array}{l}\text { News } \\
\text { article }\end{array}$ & $29 / 08 / 08$ & $\begin{array}{c}\text { Isaac } \\
\text { Yeboah/Joy } \\
\text { Online News }\end{array}$ & $\begin{array}{c}\text { Government: } \\
\text { We're selling GT to } \\
\text { save it }\end{array}$ & $\begin{array}{c}\text { Gov't justifies sale } \\
\text { of GT }\end{array}$ & $\begin{array}{c}\text { Dr. Aggrey Ntim, } \\
\text { Communications } \\
\text { Minister }\end{array}$ \\
\hline
\end{tabular}

Table 2: List of Secondary Data Sources (Example)

Source: Author Compilation

The secondary data was derived from 17 news articles/news releases, 7 annual reports of the case study companies, and 3 other related documents (see Appendix 1). Scott (1990, cited in Flick, 2009) outlined four criteria for assessing the quality of documents for inclusion in any research, namely: 1) authenticity - the evidence is genuine and of unquestionable origin; 2) credibility - the evidence is free from error and distortion; 3) representativeness - the evidence is typical of its kind); and 4) meaning - the evidence is clear and comprehensible. These four criteria were used for document selection for this study.

A more detailed description of the distribution of the secondary data sources over the study period 2008-2015 is given in Table 5.2. As evident in the table, more focus was put on the recent years following the acquisitions to shed light on the immediate post-acquisition behaviours of the companies regarding technology deployment.

\begin{tabular}{|c|c|c|c|c|c|c|c|c|c|}
\hline Type & $\mathbf{2 0 0 8}$ & $\mathbf{2 0 0 9}$ & $\mathbf{2 0 1 0}$ & $\mathbf{2 0 1 1}$ & $\mathbf{2 0 1 2}$ & $\mathbf{2 0 1 3}$ & $\mathbf{2 0 1 4}$ & $\mathbf{2 0 1 5}$ & Total \\
\hline $\begin{array}{c}\text { News } \\
\text { articles/releases }\end{array}$ & 4 & 4 & 3 & 1 & 3 & --- & -- & 2 & $\mathbf{1 7}$ \\
\hline $\begin{array}{c}\text { Vodafone Group } \\
\text { Annual Reports }\end{array}$ & --- & 1 & 1 & 1 & 1 & --- & --- & --- & $\mathbf{4}$ \\
\hline $\begin{array}{c}\text { Bharti Airtel } \\
\text { Annual Reports }\end{array}$ & --- & --- & 1 & 1 & 1 & --- & -- & --- & 3 \\
\hline Other documents & 1 & 1 & --- & --- & --- & --- & 1 & --- & 3 \\
\hline Total & 5 & 6 & 5 & 3 & 5 & --- & 1 & 2 & 27 \\
\hline
\end{tabular}

Table 3: Distribution of Reviewed Secondary Data

Sources 2008-2015

\subsubsection{Interviews}

The secondary data and literature review provided the basis for the design of the content of the interview guide and also in determining selection of the persons to be interviewed. The primary purpose of developing the selfadministered questionnaires for collecting primary data was to gain additional perspective into the findings from the secondary data sources. The researchers submitted a questionnaire personally to each of the case study companies, and one to the NCA, which were accepted with the assurance that the completed questionnaires can be picked at a later date. However, all attempts involving several follow-up visits over a three-week period to collect the completed questionnaires proved futile. None of the target respondents completed the questionnaire even after an extended period of a couple of months of following up on them. This was not surprising as other researchers conducting studies related to some aspects of telecom companies (MNOs) operations have had to face similar problems in Ghana (Sey, 2008) and elsewhere in the world (Liu, 2010). 


\subsection{Data Analysis}

Analysing the secondary data consisted of three stages:

- Collecting the relevant materials and reviewing them;

- Extracting explanations; and

- Categorizing the explanations into themes as per the study objectives.

During the first stage, the secondary data were read through and the parts of text containing relevant data were clearly extracted. In the second stage, the different explanations were extracted into MS Word. The third stage involved categorizing the explanations into themes. Themes are "abstract constructs that investigators identify before, during, and after data collection" (Ryan and Bernard, 2002, 2003) In this case study, themes are the high-level categories of explanations given by the network operators for deploying new technologies such as increased appetite for data and innovation'. This procedure included developing a codebook to reduce the data into appropriate categories (Ryan and Bernard, 2003).

\subsection{Study Validity and Reliability}

Any research design must be concerned with ensuring that the conclusions are true (valid) and accurate (reliable) so as to guarantee replicability. Although the aim of the case study presented in this study is not to build theory due to its limited focus on only two companies in a single market, validity and reliability are nevertheless of great importance. Four tests have been commonly used to evaluate or establish the quality of empirical social science research. Since case studies are one form of such social science research, these tests also are relevant to case studies (see, for example: Kidder \& Judd 1986:26-29; cited in Yin, 2009:40). The four attributes are: construct validity, internal validity, external validity and reliability. The tactics to be used when dealing with each test and the phase in which each tactic occurs in case studies are summarized in Table 4

\begin{tabular}{|c|c|c|}
\hline Attributes/ Tests & Case Study Tactic & $\begin{array}{c}\text { Phase of Research in } \\
\text { Which Tactic Occurs }\end{array}$ \\
\hline \multirow{3}{*}{ Construct validity } & Use multiple sources of evidence & Data collection \\
\cline { 2 - 3 } & Establish chain of evidence & Data collection \\
\cline { 2 - 3 } & Have key informants review draft case study report & Composition \\
\hline \multirow{3}{*}{ Internal validity } & Do pattern matching & Data analysis \\
\cline { 2 - 3 } & Do explanation building & Data analysis \\
\cline { 2 - 3 } & Address rival explanations & Data analysis \\
\cline { 2 - 3 } & Use logic models & Data analysis \\
\cline { 2 - 3 } & Do pattern matching & Data analysis \\
\hline \multirow{2}{*}{ External validity } & Use theory in single-case studies & Research design \\
\cline { 2 - 3 } & Use replication logic in multiple-case studies & Research design \\
\hline Reliability & Use case study protocol & Data collection \\
\cline { 2 - 3 } & Develop case study database & Data collection \\
\hline
\end{tabular}

\subsubsection{Construct Validity}

To ensure construct validity, several tactics were applied during the course of the study.

First, the study employed several secondary data sources to increase credibility. Furthermore, the findings from the secondary data largely reflected upon the analyses of the telecom industry environment presented to further enhance the credibility of the data. Finally, an industry insider was requested to review the case study report.

\subsubsection{Internal Validity}

For this study, the main objective of which is to investigate the influence of mergers and acquisition on the technological performance of Vodafone Ghana and Airtel Ghana the concern for internal validity is critical. Yin (2009) has pointed out that in trying to establish a causal relationship where $\mathrm{X}$ leads to $\mathrm{Y}$ can be dangerous if the investigator is not aware or neglects the presence of some intervening variables that may have caused or influenced Y. From the tactics listed in Table 5.3., this study relied primarily on explanation building and addressing rival explanations. Since it is obvious that no one explanation or a well-defined set of explanations exist to explain the extent to which mergers and acquisitions may influence the two cases to deploy new technologies. The research findings presented here merely seek to evaluate the credibility of each given explanation based on actions that seek to confirm or otherwise negate earlier statements of the case studies.

\subsubsection{External Validity}

The third test of external validity is perhaps not directly suitable for evaluating this study. Though multiple-case studies can be explained by theory and theories can be tested, the studied phenomenon here presents an evolving field of study that the existence of a single theoretical framework with explanatory power is virtually absent. However, the case study is based on a wider theoretical framework of merger and acquisition theory, especially in the fields of value creation. 


\subsubsection{Reliability}

The objective of the last test 'reliability' is to make sure that if a later investigator adopted the same procedures as described by this study, the later investigator should arrive at the same or similar findings and conclusions (Yin, 2009). To achieve reliability, this study not only discusses the data collection and analysis procedures in detail, but also presents the full database of all the secondary material used in the study (Appendices I-II). The full interview data is also available on request.

\section{Presentation of Case Study Findings}

This section presents findings of the study extracted from analysis of the secondary data. The analysis is based on pre-acquisition and post-acquisition actions/activities of the case study companies as well as other stakeholders like government and civil society that are involved the M\&A processes. Itpresents analysis of the data organised around five themes that emerged from the analysis as is discussed below.

\subsection{Themes Identified Within the Secondary Data}

Five major themes were identified from analysis of the secondary data. These are:

- Reasons and motives for acquisitions

- Legal constraints and issues

- Organizational change and restructuring

- Infrastructure development and technology deployment

- Perception of the technology

\subsubsection{Reasons and Motives for Acquisitions}

The several reasons and motives often cited for M\&A activities include exploitation of economies of scale, synergy, growth, asset divestiture, and shareholder wealth creation. It emerged from the analysis that many of these motives informed the case study acquiring firms' decisions. The intention of Vodafone Group to acquire 70 percent stake in the incumbent Ghana Telecom in August 2008 was premised on expansion to emerging mobile telephony markets that would create value to shareholders in terms of increased revenue. In a news release announcing the acquisition, Vodafone's Chief Executive, Arun Sarin was very optimistic about the deal, saying it would generate substantial benefits for Vodafone shareholders.

"Ghana is one of the most attractive markets in Africa with mobile subscribers growing at more than 55\% (per annum) and mobile penetration around 35\%. Our extensive operating experience together with our portfolio of products and services position us well to deliver a superior mobile experience ... and significantly improve financial performance". -Arun Sarin, Vodafone Chief Executive (news article \#1, news release \#2). Similarly, Bharti Airtel arrived in the Ghanaian mobile telecommunications scene in March 2010, when it acquired Zain Telecom's African operations (The Times of India, 2010). Announcing the deal, the Chairman and Managing Director of Bharti Airtel, Sunil Mittal considered the takeover as an opportunity for Airtel to expand into the virgin, but fast growing African mobile communications market.

"We are delighted at the closure of this transformational deal for India and Bharti Airtel. The transaction is the largest ever cross-border deal in an emerging market and will result in combined revenues of about $\$ 13$ billion. - Sunil Mittal, Chairman \& CEO, Bharti Airtel (Bharti Airtel news statement \#12, news article \#13).

These explicitly stated reasons confirmed the view that cross-border mergers and acquisitions are frequently being used by firms in high-tech industries to strengthen and maintain their global market niche, and for external growth (Rossi et al., 2013; Schuler and Jackson, 2001:239). In essence, M \& A activity is considered by many firms as a relatively fast and efficient way to expand into new markets and to incorporate new technologies, services and products (Evans and Padilla, 2003; Schuler and Jackson, 2001:239). Evans and Padilla (2003) for instance, have established that firms may be able to create new and improved products through mergers and acquisitions. They therefore concluded that, the "demand-side efficiencies" should be considered by competition authorities in evaluating whether to either allow or disallow a merger. The finding also supports the value creation theories which hold that mergers and acquisitions can create surplus value through increased access to new markets. Furthermore, the hubris theory states that management may strive for synergy as a rationale for M\&A decisions with the goal of maximizing profits for shareholders. This may explain why these reasons have been advanced by the case study acquirers.

\subsubsection{Legal Constraints and Issues}

The legal and political uncertainties that characterised the Vodafone acquisition of GT might have delayed the company's decision to invest on network infrastructure development and technology deployment which were expected much earlier. It became clear from the analysis that Vodafone had to carefully weigh the prevailing legal and political concerns surrounding the deal and appropriately address them before taking major strategic investment decisions. Before parliament's bipartisan ratification of the deal on August 14, 2008, the opposition led by the National Democratic Congress (NDC) had opposed the deal. The NDC minority in parliament claimed the entire process was not transparent because government failed to invite other bidders to participate in the bidding, and that the process was not competitive enough (news article \#3).

Furthermore, the Convention People's Party (CPP) and other civil society interest groups also opposed the deal, arguing that GT was a strategic national asset that must be protected and salvaged from any form of foreign control. Subsequently, a group of CPP members filed a suit in court to prevent the sale (news article \#6). It came as no surprise when the NDC government under Evans Atta Mills on assuming power after winning the December 2008 elections set up 
an inter-ministerial committee to review the deal (news article \#10). Recommendations from the committee's report led to the government and Vodafone agreeing to re-negotiate the terms through dialogue and re-engagement rather than resorting to legal means (news article \#5, news article \#8).

Immediately this issue was resolved amicably, Vodafone announced its intention in May 2009 to invest US\$700 million in upgrading GT's infrastructure (news article \#5). The announcement was the outcome of a meeting Sir John Bond, Chairman of Vodafone Group had with President Evans Atta Mills in London. Sir Bond told journalists afterwards that 'Vodafone had expected the Mills' Administration to go to court over the sale and purchase agreement of Ghana Telecom, signed last year with the previous [NPP] Administration' (news article \#5). The inference to be drawn from this analysis is that the management of Vodafone would have anticipated the implications of these legal and political issues, and were only waiting for the dust to settle before they would initiate any major investment measures.

In contrast, the Airtel acquisition of Zain operations in Ghana as part of its takeover of Zain African operations did not encounter such challenges. The fact that Zain was even a new entrant into the Ghanaian telecom market with a small telecom network could have partly explained the smooth acquisition process (NCA annual report, 2008).

\subsubsection{Organizational Change and Restructuring}

Another important theme that emerged from the secondary data is organizational change and restructuring through asset divestiture. The term "asset divestiture" refers to the extent to which acquired firms dispose of their physical assets and cut back their personnel in different areas as part of cost-saving measures (Capron, 1999:988). On acquiring majority stake in Ghana Telecom, Vodafone immediately initiated a series of measures to restructure the highly indebted GT in the context of debt reduction and improving organizational efficiency. In 2007 GT recorded a "negative working capital of 188 million dollars ... and by May 2008, this had risen to 199 million dollars" - Benjamin Aggrey Ntim, then Minister of Communications (news article \#4). This partly explained why Kwadwo Baah-Wiredu, then Minister for Finance, described the "deal as one on the best that would inject capital to salvage the company" (News article \#3). In view of this, the immediate priority of Vodafone was not on network expansion and growth, but on improving organizational effectiveness and reducing cost of operations. Asset divestiture actions the company took included significant organisational changes and cut back in personnel in certain areas.

For instance, in 2010 the company laid off 1, 331 employees which is about $55 \%$ of the total staff of 2,400 and recruited about 350 others into new roles (2010 Annual Report). In 2011, staff reductions (staff strength before the acquisition was $(4,200)$ and other organizational change processes continued aimed at further cost reductions. Other actions the company took included outsourcing of network operations, call centres and facilities to improve operational efficiency. These cost-saving and organizational efficiency measures resulted in Vodafone Ghana recording service revenue growth of 21 percent by March 2011, improving its brand awareness and increasing its mobile customer base from 1.2 million to three (3) million (Vodafone Group, 2011 annual report).

Studies have confirmed that asset divestiture, through the elimination of redundant staff and activities and inefficient management practices, improves the performance of horizontal acquisitions (Anand and Singh, 1997 cited in Capron, 1999, Tremblay and Tremblay, 1988). This often improves efficiency, the firm's turnaround as well as free resources for investment in areas like technology upgrading. However, staff reductions that Vodafone embarked on as part of its organizational change and asset divestiture processes was met with resistance from some employees and the Labour Union, with the "Union accusing the Management of not abiding by the law" (news article \#6). This prompted the Ministry of Communications to step in by appealing to parties in the dispute over the compulsory retrenchment exercise to exercise restraint, which was needed to ensure an atmosphere of peace in the company for the continued provision of "diligent services in a competitive telecom market place" (news article \#6).

A Deputy Minister of Communications, Mr Gideon Quarcoo, in a statement on Thursday, August 6, 2009 requested the Management of Vodafone "to immediately commence a new process of dialogue with the Union". Vodafone Management and the Union at "various meetings ... agreed on several points including Management ensuring that issues bordering on employee restructuring were conducted in a consultative manner such that the Union would at all times be well informed to facilitate and support Management in educating workers on labour issues". Mr Quarcoo stated (news article \#6).

This finding suggests that the intentions of management regarding asset divestiture may sometimes conflict with the interest of Unions if not properly handled. Invariably, if the internal strife is allowed to persist for long, it can affect postacquisition asset divestiture, technology and resource redeployment, and consequently the long-term performance of acquisitions. This may partly explain why Vodafone Ghana unlike Airtel could not immediately invest in network expansion.

\subsubsection{Infrastructure Development and Technology Deployment}

It emerged from the analysis that Vodafone had to delay its investment plans until its way was clear. This is because as early as August 2008, Simon Gordon, the Vodafone Group spokesman had stated that "over the next five years the U.K. company expected Ghana Telecom to invest over \$500 million in its operations and network to expand coverage" (news article \#1). This included restoring and expanding network coverage, and completing and integrating the national fibre optic backbone infrastructure, which was part of the GT acquisition package (news release \#2, news article \#4). The Vodafone acquisition also included a $3 \mathrm{G}$ license (news article \#9). It was therefore that Vodafone Ghana will immediately upgrade its $2 \mathrm{G}$ network to the more advanced $3 \mathrm{G}$ platform.

But as explained in the previous section, it was not until 2011 that Vodafone started taking concrete measures to secure external funding for network infrastructure expansion because there were some outstanding issues to be addressed first. In June 2011, the company then secured a syndicated loan of US\$115 million from the International 
Finance Corporation (IFC) of the World Bank for network expansion (news article \#8). Vodafone Ghana also had an additional funding facility of US\$240 million of which US\$203 million had been utilised by the end of March 2012 for network deployment (Vodafone Group Annual Report, 2012). The inflow of these financial resources and improved turnaround enabled Vodafone Ghana to upgrade its industry technology standard from GSM (2G) in 2009 (NCA, 2009) to 2.5G in 2010, even though it had 3G license (Ospina et al., 2012).This also enabled the company to extend the national fibre optic backbone network to the three northern regions and across the country.

"Since acquiring Ghana Telecom in 2008, Vodafone has invested US\$1.9 billion in infrastructure and capacity building to improve their network quality" - Gayheart Mensah, Vodafone Ghana Director of External Affairs (news article \#11).

These investments and network upgrading largely explained Vodafone's Ghana strong performance in the voice and mobile data market by the end of December 2014. The company ended December 2014 with a market share of $23.29 \%$, up by $1.71 \%$ from an initial share of 21.58\% as of December 2013 compared with One Touch 2008 market of 13.76\% (before acquisition). Vodafone Ghana was also the only mobile operator to have achieved this significant increase in an industry experiencing intense competition and constant change and innovation (news article \#11 and 2008 annual report).

Similarly, Airtel on acquiring Zain in June 2010 immediately upgraded its network technology to 3G (Bharti Airtel Annual Report, 2011/ 12), and by January 2012 the network was further upgraded to 3.75G (news article \#15). As a result, Airtel was described as "Ghana's fastest growing mobile phone network". Perhaps, this partly contributed to the strong performance of Airtel Money in the mobile money transfer market. Airtel Ghana announced that it had significantly increased the average monthly transactions of 500,000 in 2014 to over one million transactions in March 2015 (news article \#17). Airtel, currently is the fourth largest MNO in Ghana. Airtel's market share was 12 percent at the end of January, 2015 (NCA, 2015).

The behaviours of the two companies in the midst of stiff competition in the Ghanaian mobile phone industry suggest clearly that the acquisitions provided incentives for them to deploy new technologies in order to capture a share of the market. The analysis shows further that increased competition, customer expectations, the requirement for growth and enhancement of brand name were among the factors increasingly driving the acquired telecom firms into new technology deployment. This finding further supports the available evidence suggesting that investment in new technology is the most important determinant of consumer outcomes in mobile markets (GSMA, 2014c). Furthermore, the analysis confirmed the complexity and particular challenges faced worldwide when firms acquiring incumbent national telecom companies initially had limited scope to increase productivity or deploy new technology (European Foundation for the Improvement of Living and Working Conditions, 2005).

\subsubsection{Perception of the Technology}

One important theme that emerged from the previous section is the perception of the technology; it is derived from the category of convenience, the balance between network coverage and capacity requirements, and related subcategories such as speed and cost. For instance, Airtel Ghana describes its 3.75G network as "the most advanced internetcapable telecommunications system in Africa". It allows customers to "make video calls, access emails from just about anywhere, connect to high-speed Internet, download music, participate in video blogs", and do internet banking from their mobile phones, and without additional cost (news article \#15, Airtel Ghana website \#16). Based on the findings the network operator perceives that $3.75 \mathrm{G}$ system is a value-added technology to customers than its previous $3.5 \mathrm{G}$ system. On the basis of this, Airtel thought it could provide its customers with a technology that offers faster data transfer rates and at a lower cost, thus providing added value for customers. This enabled the company to roll out its flagship Airtel Money and other services including better quality and reliable mobile telephony, mobile Internet, roaming, international calling and other bundle packages in order to differentiate its products from others in the market.

The attitude of Vodafone towards technology deployment appears to be different. The policy position of the Vodafone Group regarding the NCA decision in 2010 to license and award its $2.6 \mathrm{GHz}$ spectrum license appear ill timed.

"At present, operators around the world use the $2.6 \mathrm{GHz}$ band predominantly to support traffic generated by PCs and laptops using dongles in locations that are capacity constrained. Coverage, not capacity, is the main issue for mobile networks in Ghana, and sub-1 GHz spectrum is more suitable for this respect. PC/ laptop penetration in Ghana" is still low. Since "the 2.6 GHz band is a capacity band and it is understood that network capacity constraints are not a problem in Ghana at present", delaying the licensing process makes economic sense (Vodafone Group Spectrum Policy Paper, 2014).

This is in contrast to the argument of the NCA that licensing spectrum in the $2500 \mathrm{MHz}-2690 \mathrm{MHz}$ band would "enhance competition in the broadband space which would result in; 1) improved product \& service development and diversity, 2) greater national/ regional access and affordability, 3) improved quality of service and value for money for the consuming public, and 4) competitive pricing and associated increased penetration, which will contribute to bridging the digital divide and attainment of socio-economic balance" (NCA, 2009).

There may be merits in each of these contrasting viewpoints. However, it is important to point out that the dynamics of licensing a spectrum and it being deployed by network operators are not the same. This is because an operator would have to analyse many factors regarding developing an optimal technology and business strategy that would ensure good returns for investments. Consequently, network operators often consider many factors before deciding on spectrum deployment. These include: 1) when there is increasing demand for enhanced services, especially mobile broadband, requiring networks to satisfy the growing demand for capacity; 2) infrastructure investments - which could either be by adding radio channels (low investment) or deploying new technologies (high investment), which is particularly important because deploying infrastructure is expensive, time consuming and uncertain; 3 ) effective business model - customers may want additional capacity, but operators must balance investment to increase capacity with the revenue they can obtain from services; 4) technology maturity - operators must deploy technologies at the right time. A 
newer technology may be spectrally more efficient and need less spectrum for the same amount of data capacity, but if it is not sufficiently mature, deployment may result in unreliable operation, and/ or devices may be scarce; and 5) multiple concurrent versions of the technology- due to large installed bases of users with handsets that only support older technologies and machine-to-machine applications that have long life cycles, operators have to support technologies for many years. The result is that operators have to devote spectrum to multiple generations of technology at the same time. For example, many Code Division Multiple Access (CDMA) operators are now supporting 1xRTT, EV-DO, and LTE. GSM operators are supporting GSM, UMTS/ HSPA, and LTE. Each technology constitutes a spectrum commitment (Rysavy Research, 2012). The implication of this analysis is that the acquisition appears to provide incentives for the case study telecom companies to expand their network infrastructure and deploy new technologies, other factors as presented above do have a role to play in determining the rate of technology deployment.

\section{Conclusions}

This chapter presents the conclusions of the study. The objective of this qualitative case study was to assess the influence of mergers and acquisitions on deployment of new mobile telecommunications technologies using two Ghanaian mobile telecommunication companies', which have experienced the activity. Specifically, the study sought to establish the reasons and motives for acquisitions; identify and document the current technologies used by mobile telecommunication companies; establish the technology and product differentiation strategies adopted by mobile telecommunication companies in order to be competitive, and assess whether mergers and acquisitions have led mobile telecommunication companies to more rapidly adopt new technologies and deploy new services.

Based on the findings, the following conclusions have been reached:

- It has been established that the telecom companies that were involved in acquiring stake in the companies that the case study covered had the intentions of expanding their global market outreach into emerging markets like Ghana where the subscriber base was still low compared to their dominant markets in the advanced economies at the time of acquisition. It can equally be concluded that they wanted to expand their brand names as well as grow their revenue base (shareholder wealth creation).

- It can be concluded that the legal and political uncertainties that characterised Vodafone acquisition of GT largely affected the company's decision to invest on network infrastructure development and technology deployment. The evidence has confirmed that Vodafone was mindful of the implications of the political climate in Ghana at that time and had to strategically deal with the issues for making major corporate decisions. In contrast, Airtel did not have much of a problem regarding legal issues.

- In the context of entering a new market that was already competitive, Vodafone had to embark on important organizational change and restructuring measures to increase operational efficiencies as well as reduce personnel costs. Though this was necessary to turnaround the once state-owned incumbent that was largely inefficient, the process had to be gradual because of labour disputes. The organisational change and the personnel rationalisation significantly reduced the total number of the company's employees and also injected some level of efficiency. Airtel on the other hand on entering the Ghanaian market did not have much of a problem with personnel issues and organizational inefficiencies because it acquired a relatively new entrant that was not an incumbent.

- Both companies made huge investments in upgrading their infrastructure and technologies following the acquisitions. Vodafone completed its national fibre optic backbone throughout the country that enabled it to provide efficient and reliable value-added products and services such as the Vodafone Business Solutions (VBS), M-Pesa money transfer services and low-cost smartphones as market differentiators. Similarly, Airtel made its presence felt by expanding its network coverage and tried to be ahead of its competitors in terms of technology deployment. This resulted in the launched of its Airtel Money transfer and other products as market differentiators.

- This study concludes that the acquisitions provided incentives for the companies to deploy new technologies in order to capture a share of the market that is highly competitive. Growing competition, customer expectations, and the need for growth largely contributed towards the acquired telecom firms' new technology deployment as shown in (2.4.1: Ghanaian Mobile Network Operators (MNOs) and Market share)

- One important theme that emerged from the previous section is the perception of the technology; it is derived from the category of convenience, the balance between network coverage and capacity requirements, and related subcategories such as speed and cost. For instance, Airtel Ghana describes its 3.75G network as "the most advanced internet-capable telecommunications system in Africa". It allows customers to "make video calls, access emails from just about anywhere, connect to high-speed Internet, download music, participate in video blogs", and do internet banking from their mobile phones, and without additional cost (news article \#15, Airtel Ghana website \#16). Based on the findings, the network operator perceives that 3.75G system is a value-added technology to customers than its previous 3.5G system. On the basis of this Airtel thought it could provide its customers with a technology that offers faster data transfer rates and at a lower cost, thus providing added value for customers. This enabled the company to roll out its flagship Airtel Money and other services including better quality and reliable mobile telephony, mobile Internet, roaming, international calling and other bundle packages in order to differentiate its products from others in the market.

- However, various other factors such as company policy, market dynamics, infrastructure investment requirements, cost-benefit analysis regarding the business model of each company, technology maturity, and multiple concurrent versions of the technology in use are also considered in deploying new technologies. 
The overall conclusion and implication of the study findings is that the acquisitions provided incentives for the case study telecom companies to expand their network infrastructure and deploy new technologies, even though other factors have played a role in determining the rate of technology deployment.

\section{References}

i. 802.11ac Technology Introduction White Paper. (n.d.). Retrieved April 8, 2015, from http://cdn.rohdeschwarz.com/pws/dl_downloads/d__application/ application_notes/1ma192/1MA192_7e_80211ac_technology.pd $\mathrm{f}$

ii. Agency Problems In Industries Undergoing Fundamental Change Applications To Telecommunications. (n.d.). Retrieved April 4, 2015, from http:/ / biblioteca.universia.net/ html_bura/ ficha/ params/ title/ agency-problems-inindustries-undergoing-fundamental-change-applications-to-telecommunications/ id/ 60397836.html

iii. Aggoud, R., \& Bourgeois, E. (2012). The Mismanagement of Mergers and Acquisitions. Retrieved April 6, 2015, from http:/ / www.diva-portal.se/ smash/ get/ diva2:537256/ FULLTEXT01.pdf

iv. Aker, J. C., \& Mbiti, I. M. (2010). Mobile Phones and Economic Development in Africa, 24(3), 207-232.

v. Amega, W. (2012). MERGERS AND ACQUISITION: VODAFONE GT CASE.

vi. Analysis of business opportunities of secondary use of spectrum: The case of TV white space for mobile broadband access. (n.d.-a). Retrieved April 15, 2015, from http:/ / academic.research.microsoft.com/ Publication/ 58565030/ analysis-of-business-opportunities-ofsecondary-use-of-spectrum-the-case-of-tv-white-space-for

vii. Analysis of business opportunities of secondary use of spectrum: The case of TV white space for mobile broadband access. (n.d.-b).

viii. Araba Sey. (2008). Mobile communication and development: a study of mobile phone appropriation in Ghana :: University of Southern California Dissertations and Theses. Retrieved April 23, 2015, from http:/ / digitallibrary.usc.edu/ cdm/ ref/ collection/ p15799coll127/ id/ 192409

ix. Ase, T. H. E. C., \& Apan, O. F. J. (n.d.). 3G MOBILE P OLICY :

x. AT\&T to Acquire T-Mobile USA From Deutsche Telekom | AT\&T. (n.d.). Retrieved April 4, 2015, from http:/ / www.att.com/ gen/ press-room?pid=19358\&cdvn=news\&newsarticleid=31703\&mapcode=

xi. Baca, M. (2015). The Wonderful World Of Mergers. Retrieved April 6, 2015, from http:/ / www.investopedia.com/ articles/ stocks/ 09/ merger-acquisitions-types.asp

xii. Bannert, V., \& Tschirky, H. (2004). Integration planning for technology intensive acquisitions. R and D Management, 34(5), 481-494. http:/ / doi.org/ 10.1111/ j.1467-9310.2004.00356.x

xiii. Barney, J. . (1988). Returns to bidding firms in mergers and acquisitions: Reconsidering the relatedness hypothesis. $\quad$ Retrieved April 27, from http:/ / www.wiggo.com/ mgmt8510/ Readings/ Readings10/ barney1988smj.pdf

xiv. Boohene, R. (2011). Analysis of the Antecedents of Customer Loyalty of Telecommunication Industry in Ghana: The Case of Vodafone ( Ghana ), 4(1), 229-240.

xv. Bresman, H., Birkinshaw, J., \& Nobel, R. (1999). Knowledge transfer in international acquisitions. Retrieved April 6, 2015, from http:/ / web.nchu.edu.tw/ pweb/ users/ arborfish/ lesson/ 8950.pdf

xvi. Cameron, E., \& Green, M. (2009). Making sense of Change Management: A Complete Guide to the Models, Tools and Techniques of Organizational Change (2nd Ed. Retrieved April 6, 2015, from http:// www.bms.lk/ download/ GDM Tutorials/ e-books/ Making Sense of Change Management.pdf

xvii. Capron, L., \& Mitchell, W. (1997). No Title, 1-33.

xviii. Chakrabarti, A., Hauschildt, J., \& Süverkrüp, C. (1994). Does it pay to acquire technological firms? R\&D Management, 24(1), 047-056. http:/ / doi.org/10.1111/ j.1467-9310.1994.tb00846.x

xix. Chen, C., \& Findlay, C. (2003). A Review of Cross-border Mergers and Acquisitions in APEC. Asian-Pacific Economic Literature, 17(2), 14-38. http:// doi.org/ 10.1046/ j.1467-8411.2003.00129.x

xx. Cheyne, D., \& H. (1999). PLC - Vodafone AirTouch: A global merger. Retrieved April 16, 2015, from http:/ / uk.practicallaw.com/ 7-101-0373

xxi. Creating a more valuable Vodafone. (n.d.-a). Retrieved April 15, 2015, from http:/ / www.vodafone.com/ content/ dam/ vodafone/ investors/ annual reports/Vodafone Annual Report 12.pdf

xxii. Creating a more valuable Vodafone. (n.d.-b).

xxiii. CREATING VALUE THROUGH MERGER AND ACQUISITION INTEGRATION. (n.d.). Retrieved April 16, 2015, from http:/ / karhen.home.xs4all.nl/ Papers/ 2/ Creating value through merger and acquisition integration.pdf

xxiv. Cricelli, L., Grimaldi, M., \& Ghiron, N. L. (2011). The competition among mobile network operators in the telecommunication supply chain. International Journal of Production Economics, 131(1), 22-29. http:/ / doi.org/ 10.1016/j.ijpe.2010.02.003

xxv. DUYSTERS, J. H. \& G. (2002). The EÚect of Mergers and Acquisitions on the Technological Performance of Companies in a High-tech Environment. Retrieved April 8, 2015, from http:/ / arnop.unimaas.nl/ show.cgi?fid=9841

xxvi. European mobile network operator mergers A regulatory assessment. (n.d.). Retrieved April 16, 2015, from http:/ / www.gsma.com/ publicpolicy/wp-

content/ uploads/2014/12/ European_mobile_network_operator_mergers-A_regulatory_assessmentWEB FINAL.pdf 
xxvii. Federal Communications Commission (FCC). (n.d.). Retrieved April 7, 2015, from https:/ / apps.fcc.gov/ edocs_public/ attachmatch/ FCC-11-103A1.pdf

xxviii. Gantumur, T., \& Stephan, A. (2007). Mergers \& Acquisitions and Innovation Performance in the Telecommunications Equipment Industry Mergers \& Acquisitions and Innovation Performance.

xxix. Gaughan, P. A. (2007). MERGERS, ACQUISITIONS, AND CORPORATE RESTRUCTURINGS. Retrieved April 7, 2015, from http:/ / www.books.mec.biz/ tmp/ books/ GBLT467T1OVL1V5PIM22.pdf

xxx. Gerpott, T. J., Ahmadi, N., \& Weimar, D. (2015). Who is (not) convinced to withdraw a contract termination announcement? - A discriminant analysis of mobile communications customers in Germany. Telecommunications Policy, 39(1), 38-52. http:// doi.org/ 10.1016/ j.telpol.2014.11.005

xxxi. Global Economic Prospects. Technology Diffusion in the Developing World 2008. (n.d.). Retrieved April 4, 2015, from http:/ / siteresources.worldbank.org/ INTGEP2008/ Resources/ complete-report.pdf

xxxii. GSMA/ Deliotte. (n.d.). What is the impact of mobile telephony on economy growth. Retrieved April 4, 2015, from http:/ / www.gsma.com/ publicpolicy/ wp-content/ uploads/ 2012/ 11/ gsma-deloitte-impact-mobile-telephonyeconomic-growth.pdf

xxxiii. Hancock, D. R, and Algozzine, B. (2006). QUALITATIVE Choosing Among Five Approaches.

xxxiv. Healy, P. M., Palepu, K. G., \& Rubak, R. C. (1990). Does Corporate Performance Improve After Mergers? Retrieved from http:/ / www.nber.org/ papers/ w3348

xxxv. Hsu, J., \& Chen, E. T. (2006). The Impact of Mergers and Acquisitions on Information Systems : A Case of A Software Industry Acquisition, 6(1), 57-66.

xxxvi. Husso, M. (2011). Analysis of Competition in the Mobile Phone Markets of the United States and Europe. Retrieved April 23, 2015, from https:/ / aaltodoc.aalto.fi/ bitstream/ handle/ 123456789/ 770/ hse_ethesis_12638.pdf?sequence=1

xxxvii. Ian F. Akyildiz, \&, David M. Gutierrez-Estevez, E. C. R. (2010). The evolution to 4G cellular systems: LTE-Advanced. Retrieved April 6, 2015, from http:/ / www.ece.gatech.edu/ research/labs/ bwn/ surveys/ ltea.pdf

xxxviii. Information Society Statistical Profiles 2009. (n.d.). Retrieved April 4, 2015, from http:/ / www.itu.int/ dms_pub/itu-d/ opb/ind/ D-IND-RPM.AF-2009-PDF-E.pdf

xxxix. Innovation, Resource Constraints, and Mergers in Network Industries. (n.d.). Retrieved April 8, 2015, from http:/ / warrington.ufl.edu/centers/ purc/ purcdocs/ papers/ 1119 Jamison_Innovation_Resource Constraints.pdf

xl. James S. Kehinde and Matthew A. Abata. (2010). MERGER AND ACQŪISITION: THE SYNERḠETIC EFFECT OF EQUITY OPERATIONAL - COST AND LOAN ON EARNINGS (CASE STUDY OF UNITED BANK OF AFRICA AND STANDARD TRUST BANK). Retrieved April 17, 2015, from http:// www.globalacademicgroup.com/journals/nigerian journal of research and production / MERGER AND ACQUISITION.pdf

xli. Jamison, M. A., \& Hauge, J. A. (2013). No Title.

xlii. Lane, P.J. \& Lubatkin, M. (1998). RELATIVE ABSORPTIVE CAPACITY AND INTERORGANIZATIONAL LEARNING. $\begin{array}{llll}\text { Retrieved April } & \text { 8, 2015, from }\end{array}$ http:/ / citeseerx.ist.psu.edu/ viewdoc/ download?doi=10.1.1.454.4347\&rep=rep1\&type=pdf

xliii. Majumdar, S. K., Moussawi, R, \& Yaylacicegi, U. (2006). The Impact of Mergers on Performance in the US Telecommunications Industry, 1988 to 2001. Retrieved from http:/ / papers.ssrn.com/ abstract=2120277

xliv. Measuring the Information Society Report 2014. (n.d.). Retrieved April 16, 2015, from http:/ / www.itu.int/ en/ ITU-D/ Statistics/ Documents/ publications/ mis2014/ MIS2014_without_Annex_4.pdf

xlv. Mergers and Acquisitions and Managerial Commitment to Innovation in M-Form Firms. (n.d.). Retrieved April 8, 2015, from http:/ / karhen.home.xs4all.nl/ Papers/ M\&A/ Hitt et al \%281990\%29.pdf

xlvi. Mergers and Acquisitions in Africa - African Development Bank. (n.d.). Retrieved April 6, 2015, from http:/ / www.afdb.org/ en/ blogs/ afdb-championing-inclusive-growth-across-africa/ post/ mergers-andacquisitions-in-africa-10163/

xlvii. Mergers and Acquisitions Motives. (n.d.). Retrieved April 8, 2015, from http:/ / economics.soc.uoc.gr/ wpa/ docs/ paper2mottis.pdf

xlviii. Mergers in the telecommunications sector: An overview of EU and national case law. (n.d.). Retrieved April 4, 2015, from https:/ / www.wsgr.com/ publications/ PDFSearch/ rosenthal-040612.pdf

xlix. Mobile Network Design and Deployment: How Incumbent Operators Plan for Technology Upgrades and Related Spectrum Needs. (n.d.). Retrieved April 14, 2015, from http://www.rysavy.com/Articles/2012_06_Rysavy Spectrum Management.pdf

1. Morgan, D. L. (2007). Paradigms Lost and Pragmatism Regained: Methodological Implications of Combining Qualitative and Quantitative Methods. Journal of Mixed Methods Research, 1(1), 48-76. http:/ / doi.org/ 10.1177/ 2345678906292462

li. MTN Group Limited Final audited results for the year ended 31 December 2006. (n.d.). Retrieved April 4, 2015, from

https:/ / www.mtn.com/ Investors/ FinancialReporting/ Documents/ ANNUALREPORTS/ 2006/ Booklet/ ar_sharehol der booklet 2006.pdf

lii. Mueller, D. C., \& Yurtoglu, B. B. (2007). Corporate governance and the returns to acquiring firms' shareholders: an international comparison. Managerial and Decision Economics, 28(8), 879-896. http:/ / doi.org/ 10.1002/ mde.1365 
liii. Orange and T-Mobile to create UK's largest mobile phone company | Business | The Guardian. (n.d.). Retrieved April 16, 2015, from http:/ / www.theguardian.com/ business/ 2009/ sep/ 08/ orange-tmobile-merger

liv. Osiakwan, E. (2008). The Case for "Open Access" Communications Infrastructure in Africa: The SAT-3/ WASC cable Ghana case study. Retrieved April 16, 2015, from http:/ / www.apc.org/ en/ system/ files/ APC SAT3Ghana 20080516.pdf

lv. Padgett, J. E., Gunther, C. G., \& Hattori, T. (1995). Overview of wireless personal communications. IEEE Communications Magazine, 33(1), 28-41. http:/ / doi.org/ 10.1109/ 35.339877

lvi. Park, M.C., Yang, D.H., Nam, C., \& Ha, Y. . (2002). Mergers and acquisitions in the telecommunications industry: Myths and reality. Retrieved April 16, 2015, from http:/ / koasas.kaist.ac.kr/ m/ handle/ 10203/ 81279

lvii. Porter, O. S. and M. (2001). Finland and Nokia: Creating the World's Most Competitive Economy. Retrieved April 22, 2015, from http:/ / www.uwi.edu/ ccfc/ wp-content/ uploads/ 2013/ 11/ Finland-and-Nokia.pdf

$\begin{array}{lllll}\text { lviii. Public Knowledge. } & \text { (n.d.). } & \text { Retrieved } & \text { April }\end{array}$ https:/ / www.publicknowledge.org/ files/ docs/ GigiSohnTestimonyonAT\&TandT-Mobilemerger.pdf

lix. Rogers Communications Inc. 2013 Annual Report. (n.d.). Retrieved April 15, 2015, from http:/ / downloads.rogers.com/ IR/ 2013-annual-report/ html5/ index.html?page=1\&server=\#

lx. Sauter, M. (2008). Beyond 3G- Bringing Networks, Terminals and the Web Together. Chichester, UK: John Wiley \& Sons, Ltd. http:/ / doi.org/ 10.1002/ 9780470741085

lxi. Shareholder Wealth Effects of Mergers and Acquisitions. (n.d.). Retrieved April 16, 2015, from http:// www.efmaefm.org/ 0EFMAMEETINGS/ EFMA ANNUAL MEETINGS/ 2005-Milan/ papers/ 262-vanfrederikslust_paper.pdf

lxii. Statistics. (n.d.). Retrieved April 16, 2015, from http:/ / www.itu.int/ en/ ITU-D/ Statistics/ Pages/ stat/ default.aspx

lxiii. Straub, T. (2007). Reasons for Frequent Failure in Mergers and Acquisitions: A Comprehensive Analysis. SpringerVerlag. Retrieved from http:/ / books.google.com/ books?id=I-2HQ2AJ9NMC\&pgis=1

lxiv. Supply Chain for Mobile Network Operator. (n.d.). Retrieved April 16, 2015, from http:/ / dspace.mit.edu/ bitstream/ handle/ 1721.1/ 62772/ 718740799.pdf?...1

lxv. TELECOM VOICE SUBSCRIPTION TRENDS 2014. (n.d.). Retrieved April 4, 2015, from http:/ / www.nca.org.gh/ downloads/ Mobile VOICE SUB dEC 2014.pdf

lxvi. Telecom Voice Subscription Trends 2015. (‥d.). Retrieved April 16, 2015, from http:/ / www.nca.org.gh/ downloads/ VoiceMarketShare January2015.pdf

lxvii. Telecommunication Use in Ghana: Research from the Southern Volta Region. (n.d.). Retrieved April 4, 2015, from http:/ / www.itu.int/ ITU-D/ pdf/ fg7/ ber001.html

lxviii. TELECOMMUNICATIONS IN GHANA. (n.d.).

lxix. The Choice Between Mergers/ Acquisitions And Joint Ventures: The Case Of Japanese Investors In The United States. (n.d.). Retrieved April 8, 2015, from http:/ / core.ac.uk/ download/ pdf/ 6635446.pdf

lxx. The Mobile Economy 2014. (n.d.). Retrieved April 4, 2015, from http:/ / www.gsmamobileeconomy.com/ GSMA ME Report 2014 R2 WEB.pdf

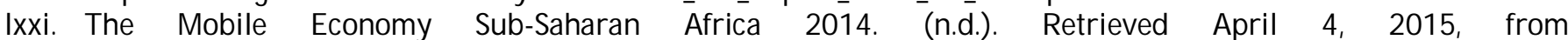
http:/ / www.gsmamobileeconomyafrica.com/ GSMA ME SubSaharanAfrica Web Singles.pdf

lxxii. Uplinq 2014 update: Steve Mollenkopf's opening keynote [VIDEO] | Qualcomm. (n.d.). Retrieved April 15, 2015, from https:/ / www.qualcomm.com/ news/ onq/ 2014/ 09/ 18/ uplinq-2014-update-steve-mollenkopfs-openingkeynote

lxxiii. Vodafone Group Plc Annual Report. (n.d.-a). Retrieved April 15, 2015, from http:/ / www.vodafone.com/ content/ dam/ vodafone/ investors/ annual_reports/ annual_report_accounts_2011.pdf

lxxiv. Vodafone Group Plc Annual Report. (n.d.-b).

lxxv. Vodafone Group Plc Annual Report For the year ended 31 March 2011. (n.d.). Retrieved April 4, 2015, from http:/ / www.vodafone.com/ content/ annualreport/ annual report11/ downloads/vf_ar2011 full_report.pdf

lxxvi. Vodafone Group. (2008). (n.d.). Retrieved April - 4, ${ }^{-}$2015, from http:/ / www.vodafone.com/ content/ dam/group/ policy/ downloads/vodafone_europe_investing_for_future_feb_2 015.pdf

lxxvii. WiMAX or LTE: Which Technology to Adopt? A Comprehensive Comparative Study. (n.d.). Retrieved April 8, 2015, from http:/ / www.ibimapublishing.com/journals/ CIBIMA/ volume9/v9n30.pdf 